\title{
"Hasta Adam” Osmanlı Devleti Karşısında Başarılı Bir İtalyan Diplomasi Örneği: Trablusgarp Savaşı
}

Hasan Tevfik Güzel*

\section{Özet}

19. yüzyılın ikinci yarısında millî birliğini sağlayan İtalya, 1815 Viyana Kongresi'nin Avrupa siyasetinde ortaya çıkardığı güçler dengesi içinde kendisine bir yer edinmeye ve aynı zamanda diğer büyük güçlerin sömürgecilik faaliyetlerinden geri kalmamaya gayret göstermiştir. Bu minvalde ilk hedefi, 1789 Fransız ihtilâli ile yayılan milliyetçilik akımlarının olumsuz etkileri karşısında istikbâlini tehdit eden sorunlarla mücadele eden ve bu sorunlara çözüm arayışı içinde olan 'hasta adam' Osmanlı Devleti'nin Kuzey Afrika'daki toprakları olmuştur. Geçmişten itibaren elde etmek istediği Trablusgarp için Avrupa'nın diğer büyük güçleri arasında son derece yoğun ve gizli bir diplomatik çaba sarf eden İtalya, Osmanlı Devleti'nin bu durumundan istifade ederek amacına ulaşmıştır. Önce Fransa ve İngiltere son olarak da İtalya'nın Afrika'nın kuzeyindeki Osmanlı topraklarını almaları ile birlikte 16.yüzyıldan itibaren bu toprakların mâliki olan Osmanlı Devleti'nin Afrika'daki varlığı sona ermiştir. Yürüttüğü açık ve gizli diplomatik faaliyetler ile sürecin kendi lehine olgunlaşmasını başarıyla sağlayan İtalya, Osmanlı Devleti'nin bu faaliyetlerden bîhaberliği ve içinde bulunduğu durumun bîçareliği karşısında sadece Trablusgarp'ı elde etmekle kalmamış özellikle günümüze kadar uzanan bir sorun niteliği taşıyan Ege Denizi'ndeki adaların akıbeti gibi stratejik konularda da söz sahibi olmayı başarmıştır. Osmanlı Devleti ise Afrika'daki varlığına son veren Trablusgarp Savaşı'nın ardından gerçekleşen Balkan Savaşları ile Balkanlardan, I. Dünya Savaşı sonucunda ise tarih sahnesinden çekilmek zorunda kalmıştır.

Anahtar Kelimeler: Trablusgarp, İtalya, Osmanlı Devleti, Diplomasi, Büyük Güçler

* Uzman, Bilecik Şeyh Edebali Üniversitesi, Bilecik, htg07@hotmail.com. (Makale gönderim tarihi: 18.10.2016, makale kabul tarihi: 26.02.2017)

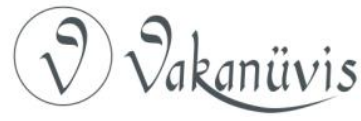




\title{
A Successful Italian Diplomacy Sample Against the Ottoman Empire "The Sick Man of Europe": Tripoli War
}

\begin{abstract}
Italy who secured its national unity in the second half of the 19th century, endeavoured to gain a position in the balance of power constituted by Congress of Vienna (1815) in European politics and also to catch up the colonial activities of other great powers. In this manner, its initial objective had been the North Africa territories of 'the sick man of Europe', Ottoman Empire who had been contending with the problems that threaten its future as a result of the bad influences of French Revolution's (1789) nationalist movements. Italy who endeavoured longstanding, vigorous and secret diplomatic efforts to land Tripoli among the other great powers of Europe, achieved this goal by taking the advantage of Ottoman Empire's situation. The presence of Ottoman Empire in Africa, as the owner of these territories since the 16th century, ceased as a result of the invasion of the Ottoman territories in the North Africa, first by France and Britain and finally Italy. Italy who ensured the process to turn into its favour both with the implicit and explicit diplomatic activities, not only invaded Tripoli as a result of wretchedness and obliviousness of the Ottoman Empire of these activities, but also has achieved to have a voice in strategic issues such as the fate of the islands in Aegean Sea which are still on the agenda. Ottoman Empire had to withdraw the Balkans by Balkan Wars occurred following the Tripoli War and has fallen out off the dusty pages of history in the wake of the World War I.
\end{abstract}

Keywords: Tripoli, Italy, Ottoman Empire, Diplomacy, Great Powers

\section{Giriş}

Osmanlı Devleti'nin 18. yüzyıl itibari ile başlayan güç kaybı giderek devletin sonunu hazırlayan bir hal almaya başlayınca devlet yönetimi bu kötü gidişata bir son verebilmek amacıyla bazı girişimlerde bulunmuştur. 18. yüzyıldan itibaren idarî, askerî, malî vb. alanlarda reform niteliğinde uygulamalar gerçekleştirilmiş ve bu çabalar ile devlet tekrar eski güçlü konumuna getirilmeye çalışılmıştır. Bu girişimlerin devamı niteliğinde 1839 Tanzimat Fermanı ve 1856 Islahat Fermanı ilan edilmiştir. Fakat bu noktada ön plana çıkan olgu Osmanlı Devleti'nin Avrupa devletleri arasındaki dengeleri göz önünde bulundurmaya başladığıdır. Nitekim 1839 Tanzimat Fermanı bir taraftan Kavalalı Mehmet Ali Paşa İsyanı karşısında sağlanan Rus

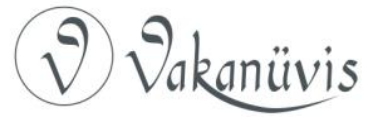


desteğinin pekiştirilmesi olarak yorumlanabilecekken diğer taraftan da akabinde Rusya ile 1833 yılında imzalanan Hünkâr İskelesi Antlaşması'ndan rahatsız olan diğer Avrupa Devletleri'nin 1841 Londra Boğazlar Sözleşmesi'nde yapılacak düzenlemelerden önce desteklerini temin etmeye yönelik bir adım olarak da değerlendirilebilir. Keza aynı şekilde 1856 Islahat Fermanı'nın ilanında da Osmanlı Devleti'nin Kırım Savaşı sonrası düzenlenen Paris Barış Konferansı'nda (1856) Avrupalı Devletlerin yanında yer almak yönündeki gayreti etkili olmuştur. Bunun belirtisi olarak da Islahat Fermanı'nın daha Paris Barış Konferansı devam ederken ilan edildiğini ve konferans temsilcilerinin bunu memnuniyetle karşıladıklarını söyleyebiliriz. ${ }^{1}$ Bu gibi çabalar neticesinde Osmanlı Devleti bu konferansta bir Avrupa devleti olarak kabul edilmiş ve bu konferans dışında Osmanlı, İngiltere ve Fransa arasında imzalanan bir diğer antlaşma ile de Osmanlı Devleti'nin bağımsızlığı ve toprak bütünlüğü bu ülkeler tarafından garanti altına alınmıştır.

Paris Barış Konferansı sonrası Avrupa içinde, özellikle güç dengeleri bakımından, cereyan eden olaylara baktığımızda ilk olarak Alman ve İtalyan millî birliklerinin kurulduklarını görmekteyiz. 18 Ocak 1871 tarihinde Almanya İmparatorluğu ilan edilmiş ve böylece Bismarck'ın hep gerçekleştirmek istediği Alman millî birliği Kral I. Wilhelm'in Imparatorluğu ve Bismarck'ın 'Şansölye'liği ile gerçekleştirilmiş oldu. İtalyan millî birliği ise aynı Alman millî birliğinin oluşturulması sürecinde olduğu gibi çeşitli aşamalardan ve savaşlardan geçtikten sonra 1870 yılında Roma'nın da 1861'de ilan edilmiş olan İtalyan Kralığı'na dâhil edilmesi ile tamamlanmıştır. Bundan sonraki süreç içerisinde İtalya'nın doğrudan olmasa da, Almanya'nın Avrupa siyasî dengelerinde çok büyük bir etkiye sahip olduğu görülmektedir. Nitekim Almanya'nın bu şekilde güçlenerek tarih sahnesine çıkmış olması komşusu Fransa'nın yanı sıra Rusya ve İngiltere'yi de çeşitli gerekçeler açısından tedirgin etmiştir. ${ }^{2}$ Almanya 1870 Sedan hezimetinin intikamını almak amacında olduğunu düşündüğü Fransa'yı Avrupa

\footnotetext{
${ }^{1}$ Fahir Armaoğlu, 19. Yüzyıl Siyasi Tarihi 1789-1914, Alkım Yayınevi, 4.Baskı, İstanbul, 2007, s.258

2 Toktamış Ateş, Siyasal Tarih I, İstanbul Üniversitesi Iktisat Fakültesi Yayınları, 1982, s.261.
}

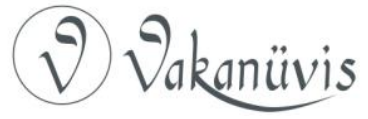


siyasî dengeleri çerçevesinde olabildiğince yalnızlığa itmeye çalışmış ve bunda da son derece başarılı olmuştur. İtalya ise Avrupa'nın büyük devletlerin kendi aralarındaki mücadelelerinden fırsatlar elde ederek sömürgeci politikasını gerçekleştirmek için büyük uğraşlar vermiştir. Italya her fırsatta Avrupa'nın iç dengelerindeki mücadelelerden kaçınmaya, tarafsı kalmaya çalışmış ve kendisine sömürge alanı yaratabilecek çabalar içine girmiştir. Bu bağlamda İtalya büyük devletler ile özellikle Osmanlı toprakları olan Afrika'nın kuzeyindeki bölgelerden elde edebilmek için anlaşmalara varmıştır.

Fransa'nın Cezayir ve Tunus'u, Ingiltere'nin de Mısır’ı işgal etmiş olması neticesinde İtalya paylaşılan Osmanlı topraklarından kendisine pay kalmayacağı korkusu ile Osmanlı'nın elinde kalan son Kuzey Afrika toprağı olan Trablusgarp'ı elde edebilmek için çok yoğun uğraşlar vermiştir. ${ }^{3}$ italya millî birliğini kurduktan sonra Tunus'u hedef seçmişse de buraya Fransa'nın sahip olması karşısında geri adım atmak zorunda kalmıştır. 1896 yılında Habeş kabileleri karşısında alınan yenilgi ile 'Büyük Devletlerin en küçüğü" olduğuna dair hakkında söylenilenlerin pekiştirilmesine sebep olan İtalya ${ }^{4}$ içerisinde bundan sonra özellikle milliyetçi İtalyanlar vakit kaybedilmeksizin son toprak parçası olan Trablusgarp'ın alınması için seslerini yükseltmeye başlamışlardır. ${ }^{5}$ italya bu bağlamda Avrupa'nın güçlü devletlerinin kendi aralarındaki mücadelelerini çok iyi bir şekilde takip etmiş ve her bulduğu fırsatta bu ülkeler ile gizli veya açık anlaşmalar gerçekleştirerek bu ülkelerin kazanımlarını tanımasına karşılık İtalya'nın da Trablusgarp'a karşı faaliyetlerinin tanınmasını sağlamıştır. İtalya'nın böylesi kazanımlar elde etmesi çok güçlü bir ülke olmamasına rağmen Avrupa içi dengeleri çok iyi okuduğu ve buna göre politika geliştirdiğini göstermektedir.

3 Mevlüt Çelebi, Milli Mücadele Döneminde Türk-italyan ilişkileri, Dışişleri Bakanlığı Stratejik Araştırmalar Merkezi, SAM Notları No.1/99, Ankara, Haziran 1999, s. 9-10

${ }^{4}$ Antony Best, Jussi M. Hanhimäki, Joseph A. Maiolo, Kirsten E. Schulze, 20. Yüzyılın Uluslararası Tarihi, Çeviren: Taciser Ulaş Belge, Siyasal Kitabevi, 2012, s.13.

${ }^{5}$ Trablusgarp'ın işgal edilmesine dair İtalyan iç siyasetindeki durumu ele alan bir çalışma için bakınız: Ronald S. Cunsolo, "Libya, Italian Nationalism, and the Revolt Against Giolitti", The Journal of Modern History, Vol:37, No:2, June 1965, s.186-207.

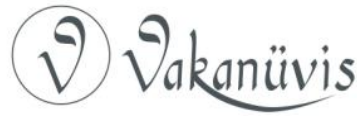


Birçok ülke ile gerçekleştirdiği bu türden antlaşmalar ile Trablusgarp konusunda kendisine bir imkân sağlayan İtalya 1911 yılı Eylül ayı içerisinde çeşitli bahaneler üreterek Osmanlı Devleti'ne karşı savaş ilan etmiş ve savaşın neticesinde imzalanan Uşi Barış Antlaşması ile de Trablusgarp'ı elde etmiştir. Afrika kıtasındaki son toprak parçasını da kaybeden Osmanlı Devleti bundan sonra kendisini I. Dünya Savaşı'na kadar götüren kötü bir sürecin içinde bulmuştur.

\section{Trablusgarp Savaşı Öncesi Durum}

19.yy'ın ikinci yarısı itibariyle millî birliklerini tamamlayan İtalya ve Almanya Avrupa siyasî dengeleri içerisinde kendilerine bir yer edinmeye çalışmışlardır. Özellikle Almanya'nın Avrupa içi dengelerde oluşturduğu yeni koşullar Avrupa'nın I. Dünya Savaşı'na kadar olan süreçteki resmini şekillendiren temel etkenler olmuştur. Bu bağlamda özellikle Şansölye Bismarck önderliğindeki Almanya'nın Avrupa siyasetinde çok daha etkin bir hale geldiğini, İtalya'nın ise Avrupa içi dengeleri oluşturan unsur olmaktansa biraz daha geri planda kalıp kendi yayılmacı amaçlarını gerçekleştirmek planları yaptığını görmekteyiz. Almanya'nın temel amacı Fransa'yı Avrupa'da yalnızlaştırmak ve kendini güvene almaktır. Bismarck 1870 Sedan yenilgisinin Fransa tarafından unutulmadığını ve bir gün muhakkak buna karşı bir hareketin gerçekleştirileceğini düşünerek Avrupa'nın diğer güçleri ile ittifaklar kurma şeklinde bir politika geliştirmiştir. ${ }^{6}$

\section{Birinci Üç İmparatorlar Ligi}

1872 yılında Almanya, Avusturya-Macaristan ve Rusya arasında kurulan bu lig özellikle Almanya'nın Fransa'ya karşı gerçekleştirdiği ilk oluşumdur. Bu üç ülkeyi bir araya getiren unsurlara bakacak olursak; Avusturya-Macaristan'ın Rusya'nın yürütmüş olduğu Panslavizm ve Almanların yürütmüş olduğu Pancermanizm politikaları karşısında bu iki ülke ile iyi geçinerek dağılma tehlikesi yaşamak istemediği görülmektedir. Rusya ise Orta Asya'da İngiltere ile bir mücadele içindeydi, Almanya'nın çok güçlü bir şekilde Avrupa siyasî sahnesine çıkmasından hoşlanmamıştı ve bir Almanya-Avusturya-Macaristan

6 Georges-Henri Soutou, Avrupa Birliği Tarihi 1815'ten Günümüze, Fransızcadan Çeviren: Eylem Alp, Bilge Kültür Sanat Yayınları, 1. Basım, Şubat 2014, s.159.

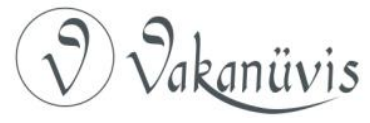


ittifakını kendisi için büyük bir tehlike olarak görmekteydi. Ayrıca Rusya, Almanya'ya karşı Fransa ile iyi ilişkiler gerçekleştirmekte ise de bu ülkeye fazla güvenmemekte idi. Almanya'nın temel amacı ise yukarıda da belirtildiği üzere Fransa'nın güçlenmesini ve Almanya'ya karşı saldırmasını önlemek için yalnızlaştırmak idi. ${ }^{7}$ Her üç ülke temsilcileri bu politikaları doğrultusunda Birinci Üç İmparatorlar Ligi'ni 7 Eylül 1872'de Berlin'de kurmuşlardır. Buna göre taraflar; Avrupa'nın mevcut durumunu kabul ediyorlar, Avrupa barışı tehlikede olursa bu durumu müzakere edeceklerini belirtiyorlar, Doğu Sorunu'nda çıkacak herhangi bir sorunu birlikte çözeceklerini söylüyorlar ve ihtilalcı hareketlere karşı birlikte hareket edeceklerini belirtiyorlardı. ${ }^{8}$

Bu kararların alınmasının ardından 1873 Nisan ayında Almanya ile Rusya arasında bir askerî antlaşma, Mayıs ayı içerisinde de Rusya ile Avusturya-Macaristan arasında bir antlaşma daha imzalanmıştır. Ancak tüm bu uzlaşılara rağmen özellikle Avusturya-Macaristan ile Rusya'nın Balkanlar üzerinde çıkarları çatışmaya ve ilişkiler gerilmeye başlamıştır.

1875'te Balkanlar'da başlayıp daha sonra 1877-78 Osmanlı-Rus Savaşı'na kadar süren kriz ortamının ardından Rusya'nın Osmanlı Devleti ile imzalamış olduğu Ayastefanos Antlaşması'nda AvusturyaMacaristan'ın haklarını hiçbir şekilde gözetmemiş olması gerginliği son raddeye getirmiş ve Ayastefanos Antlaşması yerine gerçekleştirilen Berlin Kongresi'nden sonra Birinci Üç İmparator Ligi sona ermiştir. Berlin Kongresi sırasında Avusturya-Macaristan Rusya'nın karşısında yer alan İngiltere ile sıkı ilişki içine girmiştir. Bu yakınlaşmadan FransaIngiltere yakınlaşmasından korktuğu için hiç hoşnut olmayan Bismarck, Avusturya-Macaristan'ı tekrar yanına çekebilmek için Rusya'yı göz ardı ederek Avusturya-Macaristan ile I. Dünya Savaşı'nın sonuna kadar sürecek bir ittifak anlaşmasını 7 Ekim 1879'da imzalamıştır. 5 yıllığına yapılan ancak taraflarca hiç feshedilmediği için I. Dünya Savaşı sonuna kadar süren bu ittifak genel itibariyle Rusya'ya karşı düzenlenmiş bir ittifak niteliği taşımaktaydı. Almanya bu ittifak ile Fransa'nın savaş açtığı bir durumda Rusya'nın Fransa'ya yardım etmesi halinde Avusturya-Macaristan'ın desteğini sağlarken, Avusturya-Macaristan da Rusya'ya karşı Almanya'nın desteğini almakla birlikte toprak talepleri

\footnotetext{
${ }^{7}$ Ateş, a.g.e., s.388.

${ }^{8}$ Şerafettin Turan, Türk Devrim Tarihi, 1. Basım, Kasım 1991, s. 23.
}

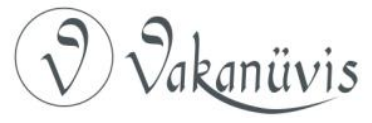


doğrultusunda İtalya'nın savaş açtığı bir durumda Rusya'nın da buna müdahil olması halinde Almanya'nın desteğini sağlamaktadır. ${ }^{9}$

\section{İkinci Üç İmparatorlar Ligi}

Bismarck Avusturya-Macaristan ile yaptığı bu ittifakın Rusya tarafından bir tehlike olarak görülüp bu ittifakın içinde yer almasına neden olmasını istemekteydi. Rusya ilk başlarda bu ittifakı kendisine karşı yapılmış hissetse de aynen Bismarck'ın düşündüğü gibi kendisini bu ittifaka dâhil olmak zorunda hissetti. Rusya'yı buna iten nedenler olarak; Ingiltere'nin özellikle Berlin Kongresi'nden sonra artık Osmanlı́nın toprak bütünlüğünü savunmamaya ve Osmanlı içinde kendisine yakın unsurları destekleyerek bunlara devlet kurdurma politikasına başlaması, İngiltere'nin Kıbrıs'a yerleşmiş olması, İngiltere ile Orta Asya'da bir mücadelenin olması ve Türk Boğazları konusunda Avrupalı Devletlerin izleyebileceği değişik politikaları sayabiliriz. Bu gibi nedenlerin neticesinde 18 Haziran 1881 yılında yine Berlin'de İkinci Üç İmparatorlar Ligi anlaşması imzalandı. Bu anlaşma öylesine gizli tutuldu ki ancak 1918 yılında açıklandı. Bu anlaşma genelinde de AvusturyaMacaristan ile Rusya arasında bir çatışma alanı olan Balkanlar bu iki ülke arasında nüfuz alanları olarak paylaştırılmıştır. Ancak tüm paylaşımlara rağmen Avusturya-Macaristan'ın Rusya'nın haklarını dikkate almayan politikalar yürütmesi neticesinde Birinci Üç Imparatorlar Ligi'nde olduğu gibi bu lig de Balkanlar üzerindeki mücadeleden (1885 yılındaki Doğu Rumeli ve Bulgaristan Krizi) dolayı bozulmuştur. ${ }^{10}$

\section{Üçlü İttifak}

Almanya'nın Fransa'yı Avrupa'dan ve kendisinden uzak tutmak istemesi ve İngiltere'nin Kıbrıs'ı almış olmasının tepkilerini azaltmak istemesi gibi nedenler neticesinde Almanya ve İngiltere Berlin Kongresi sırasında Fransa'yı Osmanlı toprağı olan Tunus'u işgal etmesi yönünde teşvik etmişlerdir. ${ }^{11}$ Doğrusu ilk başlarda bu ülkeler İtalya'ya böyle bir

\footnotetext{
${ }^{9}$ Asa Briggs-Patricia Clavin, Modern Europe 1789-1989, Longman, 1997, s.145146.

${ }^{10}$ Turan, a.g.e., s.24.

${ }^{11}$ Yusuf Hikmet Bayur, Türk İnkılâbı Tarihi, Cilt:1 Kısım: 1, Türk Tarih Kurumu Basımevi, Ankara, 1991, s.26.
}

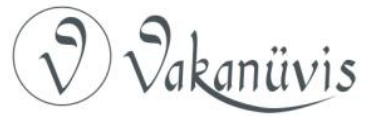


teklifte bulunmuşlarsa da Fransa ile arasının bozulmasını göze alamaması ve kendisini yeterince güçlü görmemesinden dolayı İtalya bu teklifi reddetmiş ve sonra bu ülkeler Fransa'ya yönelmişlerdir. Nihayetinde Fransa 1881 yılı itibariyle Osmanlı toprağı olan Tunus'u işgal etmiştir. Tunus teklifini çeşitli gerekçeler ile reddeden ìtalya Fransa'nın işgaline çok büyük tepki göstermiştir. Kendisi için en uygun toprak olarak Tunus'u gören İtalya bu işgalin ardından gösterdiği tepkilere hiçbir olumlu cevap alamadı. Bundan sonraki süreç içerisinde aslında kendisine pek de güvenmeyen Almanya'ya yaklaşma politikası yürüten İtalya, Almanya'nın Avusturya-Macaristan ile yaptığı ittifaka dâhil olma talebini iletti. Bismarck her ne kadar İtalyanları 'havai karakterli' ve 'çocukça egoizmlere sahip' olarak görse de Fransa'ya karşı yanına almak için bu teklifi olumlu karşıladı. ${ }^{12}$ Diğer taraftan İtalya'nın Avusturya-Macaristan'dan toprak talepleri konusu da çözüme kavuşturuldu. Bunun neticesinde Almanya, AvusturyaMacaristan ve İtalya arasında Üçlü İttifak 20 Mayıs 1882'de Viyana'da imzalandı. 5 yıllığına yapılan bu ittifakın İngiltere'ye karşı işletilmeyeceğini her üç devlet de kabul etmiştir. İtalya bu anlaşma neticesinde güçlü Almanya ile ittifaklık içerisine girerek itibar kazanmanın yanında Fransa'ya karşı diğer iki ülkeden de bir güvence almış oluyordu. Bununla İtalya, Fransa karşısında kendisini Fransa'nın elinde bulunan Nice ve Savoie şehirleri ile Kuzey Afrika'daki topraklar konusunda daha rahat hissetme fırsatı yakalamıştır. Bu bağlamda bundan sonraki süreç içerisinde İtalya'nın bu ittifaka dayanarak sömürgecilik faaliyetlerini arttırdığını ve müttefiklerinden yardım görmediği takdirde bu amaç uğruna başka politikalar gütme yoluna da gittiğini görmekteyiz. Keza italya bu ittifakın içinde yer almasına rağmen I. Dünya Savaşı'nda bu müttefiklerinin karşısında yer almıştır.

İtalya'nın Üçlü İttifak Anlaşması'ndan sonra yürütmüş olduğu sömürgecilik politikasında ilk durağı Habeşistan olmuştur. Aslında İtalya'nın Afrika'nın kuzeyindeki bölgelerde gözü olmasına rağmen Habeşistan'a yönelmesine sebep olan şey Afrika'nın kuzeyindeki Fransa ve İngiltere varlığıdır. İtalya 1885 yılında Habeşistan'ın bir kısmını işgal edebilmişse de ancak 4 yıl sonra 1889'da tamamen yerleşebilmiştir. İtalya ittifak içinde bulunduğu ülkelerin kendisine

${ }^{12}$ Armaoğlu, a.g.e., s.358.

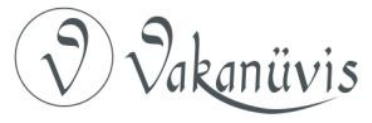


yardımcı olmamasından dolayı şikâyette bulunmaya başlamış ve yaklaşmakta olan ittifakın yenilenmesine olumlu bakmamakta idi. ${ }^{13}$ Fakat gerçekleştirilen görüşmeler neticesinde taraflar Üçlü İttifak'ın yenilenmesi anlaşmasını 1887 yılında imzalamışlardır. Bu yenileme anlaşmasının maddelerinde genel itibariyle İtalya'nın sömürgecilik faaliyetlerine destek verilmekteydi. Buna göre; Fransa eğer Fas veya Trablusgarp'ı egemenliği altına almaya çalışırsa bu durumda İtalya da Akdeniz'deki çıkarlarını korumak için aynı bölgelerde harekete geçecek ve olası bir Fransa-ittalya savaşında Almanya İtalya'ya yardım edecekti. ${ }^{14}$

\section{İtalya-İngiltere Anlaşması}

İtalya müttefiklerinden bu yönde kazanımlar elde ederken diğer taraftan da sömürge faaliyetlerinde Fransa ile çekişme halinde olan Ingiltere ile Almanya'nın da desteği sayesinde görüşmeye başlamış ve bunun neticesinde de İttifakı Yenileme Anlaşması'ndan 8 gün önce 12 Şubat 1887 'de İngiltere ile bir anlaşma imzalamıştır. Bu anlaşmaya göre; İtalya, İngiltere'yi Mısır'da destekleyecek İngiltere de İtalya'yı Trablusgarp'ta destekleyecek ve Akdeniz, Adriyatik, Ege Denizi ve Karadeniz'de mevcut durum korunmaya çalışlacaktı. ${ }^{15}$ italya böylece sömürgecilik isteklerini İngiltere'ye de kabul ettirmiş oluyordu. Bunun ardından İtalya Afrika'nın kuzeyindeki sömürgecilik faaliyetleri için kendisi açısından en büyük tehlike olarak gördüğü Fransa'ya karşı İspanya ile de Mayıs ayı içerisinde bir antlaşma imzalamıştır.

\section{İkinci Akdeniz Antantı}

İtalya'nın Rusya'nın Akdeniz'e inme tehlikesinden korkması, Avusturya-Macaristan'ın Balkanlar üzerinde Rusya ile çatışıyor olması ve İngiltere'nin Rusya'nın Akdeniz'e inmesinden korkuyor olması bu üç ülkeyi 12 Aralık 1887'de İkinci Akdeniz Antantı'nı imzalamaya sevk eden nedenler olarak sıralanabilir. ${ }^{16}$ Anlaşmanın ilkeleri genel itibariyle Rusya'nın Osmanlı üzerinden Akdeniz'e inmesini engellemeye dönüktü

\footnotetext{
${ }^{13}$ Commodore W. H. Beehler, 1911-1912 Türk-italyan Savaşı, Çevirmen: Leyla Yıldırım, İlgi Kültür Sanat Yayınları, İstanbul, 2014, s.10.

${ }^{14}$ Armaoğlu, a.g.e., s.366-367.

${ }^{15}$ Briggs, a.g.e., s.147; Armaoğlu, a.g.e., s.367-368.

${ }^{16}$ Bayur, a.g.e., s.60-61.
}

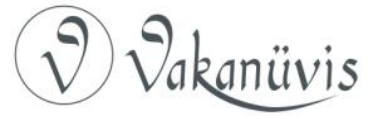


ve bunun için de Osmanlı toprakları merkez alınarak Osmanlı'nın bağımsızlığının her türlü yabancı etkiye karşı korunacağı belirtilmiştir. Anlaşmanın garip bir maddesi ise şöyleydi; Osmanlı Devleti kendi toprakları üzerinde bazı ülkeler ile işbirliği haline girecek olursa veya taraflar bu şekilde hareket ettiğine kanaat getirirlerse Osmanlı Devleti'nin gerekli gördükleri kara veya deniz kıyısındaki bazı yerlerini işgal edebileceklerdi. ${ }^{17}$ Görüldüğü üzere bu üç ülke de kendi çıkarlarına halel gelmemesi için Rusya'nın Akdeniz'e inmesine karşı her türlü girişimde bulunmakta ve hatta bu amaç uğruna Osmanlı'nın toprakları üzerinde söz sahibi gibi davranmaktadırlar. Bu durum da Osmanlı Devleti'nin 19.yy sonları itibariyle içine düştüğü sıkıntılı durumu gözler önüne sermektedir.

\section{Üçlü Anlaşma (İtilaf)}

Almanya'nın Fransa'ya karşı gerçekleştirmiş olduğu yalnızlaştırma politikası başarılı olmuştu. Almanya çeşitli anlaşmalar ile AvusturyaMacaristan, Rusya, İtalya, İspanya gibi ülkeler ile ittifak içerisinde bulunmuştur. Ancak daha sonraları kendisi için gerçek potansiyel düşman olarak gördüğü Avusturya-Macaristan ile özellikle Balkanlar üzerinde çatışması neticesinde Rusya bu oluşumdan yavaş yavaş uzaklaşarak Fransa ile yakın ilişkiler kurmaya başlamış ve Almanya'nın kurduğu bu ittifaklar yapısını ortadan kaldırabilmek için kendisine müttefikler arayan Fransa ile yapılan görüşmeler 1894 yılında bir ittifak halini almıştır. ${ }^{18}$ Bunun haricinde Kıta Avrupa'sı siyasî gelişmelerini dışarıdan izleyerek gerektiğinde denge sağlayabilmek amacıyla müdahale eden, Fransa ile özellikle Afrika'nın kuzeyinde bir rekabet içerisinde bulunan İngiltere de Avrupa'da güçlü bir konuma gelen Almanya'nın daha fazla güçlenmesini engellemek adına denge kurmak amacıyla Fransa ile sıkı ilişkiler içine girmeye başlamıştır. Bu ilişkilerin neticesinde zaten Almanya'ya karşı müttefik arayışı içinde bulunan Fransa ile 8 Nisan 1904'te 'Entente Cordiale' denen Samimi Anlaşma Londra'da imzalanmış ve buna göre Fransa, İngiltere'nin Mısır

\footnotetext{
${ }^{17}$ Armaoğlu; a.g.e., s.380.

${ }^{18}$ Soutou, Avrupa Birliği..., s.179-180. 1891 yılında Fransız savaş donanmasının Rus limanını ziyaretiyle başlayan süreç genelkurmay başkanlarının yürüttüğü müzakereler neticesinde bu noktaya ulaşmıştır. Bayur, a.g.e., 69, 71, 74, 8081; Briggs, a.g.e., s.150.
}

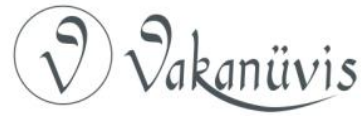


üzerindeki tahakkümünü kabul ederken, İngiltere de Fransa'nın Fas'a yönelik emellerine karşı çıkmayacaktı. ${ }^{19}$

Üçlü Anlaşmayı tamamlayacak olan girişim, zincirin son halkası olan Ingiltere ile Rusya'nın anlaşmaları idi. Bu noktada özellikle İran ve Afganistan üzerindeki mücadelelerini bir nihayete erdiren İngiltere ile Rusya 30 Ağustos 1907'de bir anlaşma imzalayarak Üçlü Anlaşma'yı (Itilaf) gerçekleştirmişlerdir. ${ }^{20}$

Üçlü Anlaşma'nın da gerçekleşmesi ile birlikte Avrupa siyaseti iki kutba ayrılmıştır. Bir tarafta Üçlü İttifak ülkeleri Almanya, AvusturyaMacaristan, İtalya ve diğer tarafta da Üçlü Anlaşma ülkeleri Fransa, Ingiltere ve Rusya bulunmaktadır. Bu iki kutup arasındaki mücadeleler bundan sonraki süreç içerisinde daha da artmış ve 1914'te patlak veren I. Dünya Savaşı'na kadar uzanmıştır. Bu süreç içerisinde Üçlü Itttifak içinde yer alan İtalya kendi sömürgecilik faaliyetlerini gerçekleştirmek için bütün fırsatları değerlendirmiş ve dağılmasına muhakkak gözü ile baktığı Osmanlı toprakları üzerinde işgal faaliyetleri yürütmüştür. $\mathrm{Bu}$ sömürge faaliyetleri bağlamında kendi müttefiklerinden yardım alamadığını düşündüğü takdirde diğer ülkelerle de sıkı ilişkilere girmekten çekinmeyen italya nihayetinde yürütmüş olduğu bu politikasında başarılı olmuş ve bir Osmanlı toprağı olan Trablusgarp'ı işgal etmiştir.

\section{Trablusgarp Savaşı}

Millî birliğini sağladıktan sonra diğer Avrupa devletlerinin gerçekleştirmiş olduğu sömürgecilik faaliyetlerinden geri kalmak istemeyen İtalya, sömürge alanı olarak Tunus'u kendisine seçmişse de Ingiltere ve Almanya'nın Tunus'u Fransa'ya 'bahşetmeleri' neticesinde Fransa'ya karşı mücadele edebilecek kadar güçlü olmayınca kısa süreliğine sömürgecilik faaliyetlerinden 'mahrum' kalmıştır. Bir müddet Tunus'u alabilme umudu taşıyan İtalya 1881 yılında Fransa'nın Tunus'u işgal etmesinin ardından yeni sömürge alanı olarak seçtiği Habeşistan'dan 1896 yılında imzalanan bir anlaşma neticesinde de geri dönmek zorunda kalınca bölgede sömürgecilik alanında yeni bir güç merkezi olma düşüncesi ile Afrika'nın kuzeyindeki bir diğer Osmanlı

\footnotetext{
${ }^{19}$ Soutou, a.g.e., s.186., Best, a.g.e., s.20., Turan, a.g.e., s.25-26.

${ }^{20}$ Ateş, a.g.e., s.403.
}

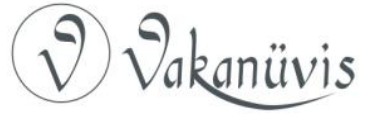


toprağı olan Trablusgarp ve Bingazi'ye yönelmiştir. ${ }^{21}$ Özellikle bu tarihten sonra Fransa ve İngiltere'nin Afrika'nın kuzeyindeki faaliyetlerine karşı güvence olarak dâhil olduğu Üçlü İttifak içerisinde de kendisinin bu bölgeler ile ilgili emellerini müttefiklerine kabul ettirmeye çalışan İtalya bunda da başarılı olmuştur. Bu bağlamda Üçlü İttifak'ın yenileneceği 1887 yılındaki görüşmelerde İtalya, müttefiklerinden sadece Almanya'dan Fransa'ya karşı Kuzey Afrika'da gerçekleştireceği bir faaliyette destek sağlamıştı. İtalya diğer taraftan sömürgecilik politikalarını gerçekleştirmek için diğer ülkeler ile de irtibat halinde idi. 1900 yılı Aralık ayında Fransa ile bir anlaşma imzalandı. Bu anlaşmaya göre Fransa İtalya'nın Trablusgarp üzerindeki, Italya da Fransa'nın Fas üzerindeki emellerini karşılıklı olarak tanımaktaydılar. ${ }^{22}$ Bunun ardından İtalya Üçlü İttifak'ın tekrar yenileneceği 1902 yılındaki görüşmelerde bu defa 1887 yenilemesinde İtalya'nın Trablusgarp üzerindeki emellerini tanımayan AvusturyaMacaristan'ın da bu İtalyan emellerini tanımasını sağlamıştır. Üçlü Ittifak'ın Haziran ayındaki yenileme anlaşmasından sonra İtalya ve Fransa gizli bir anlaşma yaparak herhangi bir saldırıya maruz kalmaları halinde tarafsız kalacaklarını taahhüt ediyorlardı. ${ }^{23}$ Görüldüğü gibi İtalya kendi sömürge politikalarını sağlama alabilmek için birkaç ay öncesinde kendisini bağı kıldığı bir anlaşmanın ruhuna aykırı faaliyetlerde bulunmaktan hiç çekinmemektedir. İtalya bundan sonra da gerektiği noktalarda müttefiklerinin karşısında yer almaya başlamıştır. Bir taraftan Fransa ve İngiltere ile iyi ilişkiler içinde bulunmaya çalışan Üçlü İttifak üyesi İtalya, diğer taraftan da bu ittifakın üyesi olan Avusturya-Macaristan ile arasının bozulmasına neden olabilecek faaliyetlerde bulunmaya ve Adriyatik ve Arnavutluk üzerinde irredendist politikalar uygulamaya başlamıştır. Bunun haricinde 1906 yılında Almanya ile Fransa arasında vuku bulan Fas Krizi sırasında İtalya, müttefiki Almanya'yı hiçbir surette desteklememiştir.

${ }^{21}$ David G. Herrmann, "The Paralysis of Italian Strategy in the Italian-Turkish War, 1911-1912", The English Historical Review, Vol.104, No. 411, April 1989, s.333.

22 Stanford J. Shaw; Ezel Kural Shaw; History of the Ottoman Empire and Modern Turkey, Volume II, Reform, Revolution and Republic: The Rise of Modern Turkey 1808-1975, Cambridge University Press, 1977, s.289.

${ }^{23}$ Bayur, a.g.e., s.170.

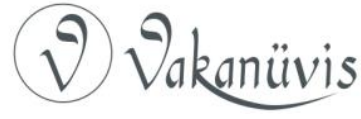


1908 yılına gelindiğinde İtalya Trablusgarp üzerindeki emellerini yapmış olduğu açık veya gizli anlaşmalar ile çoğu Avrupa devletine kabul ettirmiş bulunmaktaydı. 1908 yılı içerisinde AvusturyaMacaristan'ın Bosna-Hersek'i ilhak etmesi Adriyatik'i kendi denizi olarak gören İtalya'nın tepkisine sebep olmuştur. Bunun sonrasında Avusturya-Macaristan'ın Balkanlar'daki faaliyetlerinden rahatsız olacağını düşündüğü Rusya ile irtibata geçen İtalya Rusya ile 24 Ekim 1909'da Racconigi Antlaşmasını imzalamıştır. Buna göre; Balkanlarda mevcut durum korunacak, taraflardan birisi Avusturya-Macaristan ile bir anlaşma yapacak olursa bu ancak diğer tarafın da katılımı ile olacak ve İtalya Rusya'nın Türk Boğazları'ndaki menfaatlerini, Rusya da italya'nın Trablusgarp'taki menfaatlerini tanıyacaktı. Racconigi Antlaşması ile İtalya Trablusgarp üzerindeki emellerini son büyük devlet olan Rusya'ya da kabul ettirmiş olmaktadır. ${ }^{24}$

İtalya'nın Trablusgarp üzerindeki emellerini Rusya'ya da kabul ettirmesinin ardından artık İalya uygun zamanı kollamaya başlamıştır. Bu noktaya gelinceye kadar İtalya'nın Avrupa siyasî dengelerini çok iyi takip ettiğini; genelde sadece kendi sömürgecilik faaliyetlerini gerçekleştirmek için uğraş verdiğini, Avrupa'nın güçlü devletlerinin mücadelelerine pek müdahalede bulunmadığını ve sömürgecilik faaliyetleri için yeri geldiğinde hiç çekinmeden zıt kutuplar içerisinde yer alabildiğini görmekteyiz. Belirtildiği gibi bundan sonra italya Trablusgarp hareketi için fırsat kollamaya ve resmen gün saymaya başlamıştır. Nihayetinde İtalya o fırsatın 1911 Eylül ayı olduğuna kanaat getirmiş ve Osmanlı Devleti'ne savaş ilan etmiştir.

\section{Savaşı Hazırlayan Etkenler}

1510 yılında İspanyol işgaline uğrayan ve 1523 yılında da Saint Jean Şövalyeleri'nin eline geçen Trablusgarp 1551 yılında Osmanlı topraklarına dâhil edilmiştir. ${ }^{25}$ Bundan sonraki süreçte Trablusgarp Osmanlı Devleti'nin Akdeniz'deki faaliyetlerinde bir merkez haline gelmiştir. Akdeniz'in bir Türk gölü haline gelmesi sürecinde çok büyük öneme sahip Trablusgarp valiliğine 1712 yılında burada görev yapan

24 Enver Ziya Karal, Osmanlı Tarihi, IX. Cilt, Türk Tarih Kurumu Basımevi, Ankara, 1996, s.264.

${ }^{25}$ Ahmet Kavas, "Trablusgarp", islam Ansiklopedisi, Cilt.41, 2012, s.288.

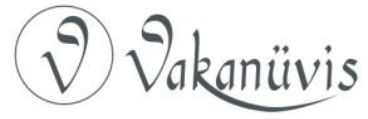


yeniçerilerin oluşturduğu kuloğullarına mensup Karamanlı Sülalesinden olan Ahmet Bey'in gelmesi ile birlikte Trablusgarp Osmanlı merkezî yönetimi ile idarî bağlarını iyice zayıflatmış ve Akdeniz üzerinde zaman zaman korsanlık faaliyetlerinde bulunmaya başlamıştır. ${ }^{26} 1830$ yılında Cezayir'in Fransa tarafından işgal edilmesinin ardından benzerî bir durumun Trablusgarp için de olabileceği korkusu ile Osmanlı yönetimi harekete geçmiş ve Trablusgarp'a kuvvet göndererek Karamanlı sülalesinin merkezî yönetimden ayrı ve keyfî yönetimine son vermiştir. ${ }^{27}$ Bundan sonra Trablusgarp valileri eskiden olduğu gibi doğrudan İstanbul'dan atanmaya başlamış ve atanan valiler Trablusgarp üzerinden Afrika içlerine doğru Osmanlı hâkimiyetinin genişlemesi için uğraş vermişlerdir.

Özellikle 1877-78 Osmanlı-Rus Savaşı'nın Osmanlı açısından büyük bir hezimet olması Osmanlı toprakları üzerinde gözü olan devletleri harekete geçirmiştir. Bu devletler arasında yer alan italya da kendisi için uygun gördüğü Tunus'un Fransa tarafından işgalinden sonra Trablusgarp üzerindeki faaliyetlerini arttırmıştır. Bu bağlamda italya Trablusgarp'ta bir deniz yolu acentesi kurmuş, Osmanlı yönetimindeki uzun tartışmaların ardından Banco Di Roma isminde bir banka açmış, gerek bu banka aracılığıyla gerekse de şahsî olarak toprak ve emlak satın almış, İtalyan okulları, hastane, dispanser ve postaneler açmış ve Osmanlı yönetiminin izni ile fosfat ve altın madenlerini arama ve çıkarma yetkisine sahip olmuştur. ${ }^{28}$ Özellikle Trablusgarp ve İstanbul'daki bazı yöneticiler İtalya'yı askerî bir işgal teşebbüsünün masraflarından kurtarmak ve bölgeye İtalya'nın girişini kolaylaştırmak amacıyla Banco Di Roma'nın açıldığını belirterek sert bir şekilde buna karşı çıkmışlardır. Banco Di Roma ile ilgili bir diğer husus da günümüzde cereyan eden savaşların iç yüzleri ile benzerlik göstermektedir. Banka'nın üst düzey yöneticileri arasında o dönem

26 İsrafil Kurtcephe, Türk Italyan ilişkileri (1911-1916), Türk Tarih Kurumu Basımevi, Ankara, 1995, s.4-5.

${ }^{27}$ Orhan Koloğlu, "Libya, From the Ottoman Perspective (1835-1918)", Africa: Rivista trimestrale di studi e documentazione dell'Istituto italiano per l'Africa e I'Oriente, Anno 63, No. 2, La Libia nella storia del Mediterraneo. Atti del Convegno, Roma, 10-12 maggio 2003 (Giugno 2008), s.276.

${ }^{28}$ Kurtcephe, a.g.e., s.15-18

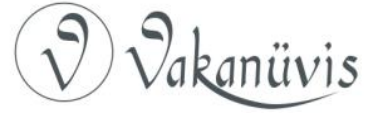


İtalya Dışişleri Bakanı Tittoni'nin kardeşi, siyasetçi, üst düzey bürokratlar ve kiliseye mensup din adamları bulunmakta ve bu kişiler Trablusgarp'ı İtalya için vazgeçilmez bir sömürge alanı olarak gösterip hem siyasî hem dinî hem de ekonomik açıdan kâr elde etme gayreti göstermektedirler. ${ }^{29}$ Trablusgarp Savaşı boyunca İtalyan ordusu için açılan ihalelerin hepsini sadece Banco Di Roma kazanmıştır. Yani savaşı çıkartanlar ile savaşın nimetlerinden yararlananlar aynı kişiler olmuşlardır.

Osmanlı Devleti ise daha 1876 yılından itibaren İtalya'nın Trablusgarp'a yönelik girişimlerinden haberdar olmasına rağmen buraya yönelik tedbirleri yeterince almamıştır. 1876 yılında ilk Meclis-i Mebusan'da bazı mebuslar İtalya'nın bu girişimlerine dikkat çekmiş ve acilen tedbir alınmaması halinde Trablusgarp'ın da kaybedileceğini belirtmişlerdir. II. Abdülhamit italyan girişimlerinin bilincinde olarak Italya'nın girişimlerini klasik 'denge politikası' ile bertaraf etmeye çalışmıştır. Bu bağlamda 1905 yılında İtalya'nın Trablusgarp üzerindeki bazı imtiyaz taleplerine karşı Fransa'ya başvurarak; bu durumun Fransa için de kötü sonuçlar doğurabileceğini belirtmiş ve Fransa ile bir ittifak kurma çabası içinde bulunmuştur. ${ }^{30}$ II. Abdülhamit italya'nın isteklerini Fransa vasıtası ile yok etmek amacındayken Fransa hiç tereddütsüz Italya'yı desteklemiştir. Bunda şüphesiz İtalya ile Fransa'nın Kuzey Afrika ile ilgili gerçekleştirmiş oldukları anlaşmalarda vardıkları kararlar etkili olmuştur. Bunlardan habersiz Osmanlı yönetimi Trablusgarp limanı inşası ihalesini de yine denge politikası uygulamak adına Fransa'ya vermiş ancak bir sonuç elde edememiştir. Bunun yanında İtalya'nın Bingazi ile ilgili taleplerine karşılık II. Abdülhamit onlara Irak'ta bazı imtiyazlar vermeyi talep etti. Bu noktada Osmanlı Yönetimi'nin İtalya'yı Irak'a yönlendirerek burada Alman ve İngiliz çıkarları ile çatışmasını sağlamaya çalıştığını görmekteyiz. II. Abdülhamit'in bu teklifini çok kurnazca bulduğunu hatıralarında belirten dönemin İtalya Başbakanı Giolitti Almanya ve İngiltere ile

29 Richard A. Webster, "The Political and Industrial Strategies of a Mixed Investment Bank: Italian Industrial Financing and the Banca Commerciale 1894-1915", VSWG: Vierteljahrschrift für Sozial- und Wirtschaftsgeschichte, 61. Bd., H. 3(1974), s.355-360.

${ }^{30}$ Karal, a.g.e., s.262-263.

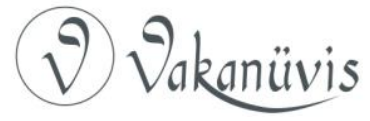


çatışmamak için bu teklifi kabul etmediklerini söylemektedir. ${ }^{31}$ II. Abdülhamit yönetiminde askerî tedbir olarak da asker mevcudu 20.000 'e çıkarılmış ve Kuloğulları teşkilatı yeniden düzenlenerek ihtiyaç halinde 40-50 bin kişilik kuvvet çıkarabilecek hale getirilmiştir. Ayrıca İslamcılık fikrini savunan II. Abdülhamit bölgede yaşayan Müslüman unsurları bir arada tutmaya çalışmıştır. Bölge üzerinde etkin olan Senusilere $^{32}$ top, silah ve cephane göndermiştir.

1908 yılında II. Meşrutiyet'in ilan edilmesinden sonra itttihat ve Terakki taraftarı olan Trablusgarp valisi Recep Paşa'nın yerine vekil olan vali halkın büyük tepkisine sebep olmuş ve Recep Paşa ile beraberindeki İttihat ve Terakki grubu üyesi çok sayıda kişi Trablusgarp'ı terk etmek zorunda kalmıştır. Böylesi bir durumun ortaya çıkmasının ardından olayların yerinde incelenmesi için Erkan-ı Harp Kolağası Mustafa Kemal görevlendirildi. Görevlendirilmenin, İttihat ve Terakki Komitesi Genel Merkezi'nin Selanik'te gerçekleştirdiği bir toplantı esnasında bizzat üyesi olmasına rağmen kendisinden habersiz, emri vaki olarak İstanbul'dan gelen bir mektup aracilı̆̆ıla Mustafa Kemal'e tevdi edilmesi ${ }^{33}$ gelecek yıllarda ülke müdafaası için beraber hareket edecek olan kadro ile Mustafa Kemal'in fikir ayrılıklarının ilk emareleri olarak kabul edilebilir. Ayaklananlar ve bölgenin ileri gelen şeyhleri ile görüşen $\mathrm{M}$. Kemal halka hitaben yaptığı konuşmalarda din kardeşliğinden bahsederek birlik ve beraberliğin yaratacağı gücün devletin varlığını korumakta kullanılacağına dair söz verdi ve halkı devleti güçlendirmek için işbirliği yapmaya davet etti. ${ }^{34}$ Bundan sonra halk ayaklanmayı sona erdirip yeni hükümetin otoritesini kabul etti. Ardından Bingazi'ye geçen M. Kemal burada da halk üzerinde çok büyük etkisi olan Şeyh Mansur'u etkisiz hale getirdikten sonra İstanbul'a dönmüştür. Bundan sonra Trablusgarp ve Bingazi'de İtalya aleyhine propaganda hareketleri gerçekleştirilmiştir.

\footnotetext{
${ }^{31}$ Kurtcephe, a.g.e., s.20.

32 Senusiler ile ilgili bilgi için bakınız: Ahmet Kavas, "Senusiyye", islam Ansiklopedisi, Cilt: 36, 2009, s.536-537.

33 Âfet İnan, "Trablusgarp'ta Hürriyete Karşı İsyan”, Belleten, Cilt:VIII, Sayı:31, Temmuz 1944, s.388.

${ }^{34}$ Genelkurmay Askerî Tarih ve Stratejik Etüt Başkanlığı, 1911-1912 OsmanlıItalyan Harbi ve Kolağası Mustafa Kemal, Kültür ve Turizm Bakanlığı Yayınları, Ankara, Haziran 1985, s. 14-16., Kurtcephe, a.g.e., s.23.
}

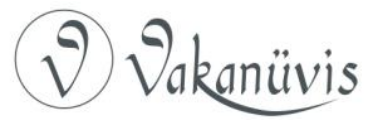


Meşrutiyet yönetiminin II. Abdülhamit dönemi sadrazamları yerine kendilerine yakın isimleri yönetimin başına getirme istekleri doğrultusunda sadrazamlığa 1909 yılında istifa eden Hüseyin Hilmi Paşa'nın yerine Roma eski elçisi Hakkı Paşa getirilmiştir. Hakkı Paşa'nın Italya'yı çok iyi tanıyor olmasından dolayı İtalya'ya karşı daha iyi önlemler alabileceği tahmin edilirken Hakkı Paşa da bu konuda bir şey yapamamıştır. ${ }^{35}$ Diğer taraftan bu dönem içerisinde Kuloğulları teşkilatı kapatılmış, işgalden birkaç ay önce Yemen'de çıkan isyanları bastırmak için bölgede bulunan askerlerin büyük bir kısmı Yemen'e gönderilmiş ama yerlerine yeni birlikler gönderilmemiş, II. Abdülhamit döneminde bölgedeki yerel güçler için tahsis edilen silahlar işgal başladığı sırada yeni modelleri ile değiştirilmek için İstanbul'a getirilmiş ancak yerlerine yenileri gönderilmemiş, 1910 yılına kadar bölgede görevli subaylar genellikle yerel dilleri bilen ve bölge coğrafyasını çok iyi bilen kişilerden seçiliyorken bu tarihten sonra Türkçe'nin dışında dil bilmeyen ve bölge coğrafyasını hiç tanımayan kişiler görevlendirilmiş, 1907 yılından itibaren Trablusgarp ve civarında ortaya çıkan kıtlık karşısında yüzlerce insan ölmüş ve yüz binden fazla insan da Mısır ve Tunus'a göç etmiş, Osmanlı yönetimi bölgeye yardım kararı almışsa da bu kararın çok küçük bir kısmı gerçekleştirilebilmiş ve bu durum da bölge halkının devlete olan güveninin sarsılmasını ve İtalya'nın da bu durumu istismar etmeye başlamasını beraberinde getirmiştir. ${ }^{36}$

İtalyanların Trablusgarp'ı işgal etmeye yönelik faaliyetleri hakkında çeşitli raporlar ve telgraflar Meclis'e ulaştırılmaktaydı. Bu raporlardan bir tanesi de Trablusgarp valisi İbrahim Paşa'ya aitti. Paşa, yönetimin derhal önlemler alması gerektiğini aksi takdirde Trablusgarp'ın kaybedilebileceğini belirtmekte idi. Ayrıca Ibrahim Paşa Trablusgarp'taki İtalyan teşebbüslerine de zorluklar çıkartarak sürecin yavaşlamasını sağlamaya çalışıyordu. Bu çerçevede hareket eden İbrahim Paşa Trablusgarp Belediye Başkanı Hassune Paşa'nın da İtalyan Bankası ile İtalya'nın çıkarları doğrultusunda işbirliği içinde olduğunu

${ }^{35}$ Tahsin Ünal, Türk Siyasi Tarihi 1700-1958, Kamer Yayınları, 6.Baskı, İstanbul, 1998, s.498, Samiha Ayverdi, Türk Tarihinde Osmanlı Asırları, Kubbealtı Neşriyatı, 4.Baskı, İstanbul, 1999, s.695.

${ }^{36}$ Kurtcephe; a.g.e., s.25-26.

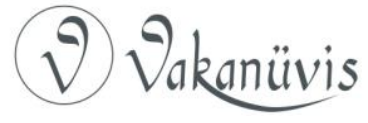


tespit etmiştir. ${ }^{37}$ íbrahim Paşa'nın Trablusgarp'ta yabancı ülkelerin faaliyetlerine yönelik tavizsiz tutumu karşısında İtalya İbrahim Paşa'nın görevden alınması için yoğun baskılarda bulunmuş ve nihayetinde Ibrahim Paşa Ağustos 1911'de görevinden alınmıştır. ${ }^{38}$ Yerine atanan Bekir Sami Bey ise Trablusgarp'a gitmekte acele etmemiş ve savaş başladığında hâlâ İstanbul'da bulunmaktaydı. Ayrıca hem valilik hem de kumandanlık görevini yürüten İbrahim Paşa'nın görevden alınmasının ardından bir kumandan atanmamasından dolayı Miralay Neşet Bey bu görevi vekâleten yürütmekteydi. Yani Osmanlı yönetimi Italyan saldırısı öncesi Trablusgarp'ı valisiz, kumandansız ve silahsız bırakmış gibi görünmekteydi.

\section{Savaş Öncesi Son Gelişmeler}

1911 yılı itibariyle Almanya ile Fransa arasında Fas üzerinde cereyan eden kriz neticesinde İtalya, Fransa ile daha önce imzaladığı anlaşmaları dayanak göstererek Trablusgarp'a bir harekâtta bulunma yönünde daha hareketli günler yaşamaya başladı. İtalya ilk başlarda savaş yolu ile değil diplomatik çabalar doğrultusunda Trablusgarp'ı ele geçirmeyi planlamaktaydı. Bu noktada kendisinin müttefiki ve Osmanlı'nın dostu olan Almanya'yı araya sokarak Osmanlı'yı razı etmeye çalıştı. ${ }^{39}$ Bu yöndeki bütün girişimlerini çok büyük bir gizlilik içinde gerçekleştiren İtalyan hükümeti Osmanlı'yı hiçbir şekilde kuşkulandırmamak gayreti içerisindeydi. Osmanlı Devleti'ne sürekli

${ }^{37}$ Fransızların 1881 sonrası Tunus'ta Hüseynî hanedanlığını hükümdar olarak tayin ettiği gibi kendisinin de İtalyanlar tarafından Osmanlı sonrası dönem için hükümdar tayin edileceğini düşünmesi İtalyan çıkarlarına hizmet eden diğer bazı Müslim-gayrimüslim toplulukların yanında Hassune Paşa'yı bu tutuma sürükleyen önemli etkenlerden biri olmuştur. Ali A. Ahmida, "From Tribe to Class: The Origins and the Politics of Resistance in Colonial Libya", Africa: Rivista trimestrale di studi e documentazione dell'Istituto italiano per l'Africa e l'Oriente, Anno 63, No. 2, La Libia nella storia del Mediterraneo. Atti del Convegno, Roma, 10-12 maggio 2003 (Giugno 2008), s.305.

${ }^{38}$ Bayur, a.g.e., 2/1, s.79.

39 Almanya'nın bu noktada italya ile müttefiklik ve Osmanlı ile dostluktan ziyade her iki ülke karşısında da kendi çıkarlarını gözeten 'ince' bir diplomasi yürüttüğü belirtilebilir. Daha detaylı bilgi için bakınız: W. David Wrigley, "Germany and the Turco-Italian War, 1911-1912", International Journal of Middle East Studies, Vol.11, No.3, May 1980, s.313-338.

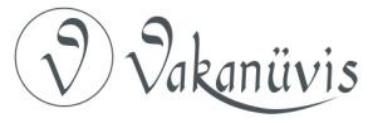


İtalya'nın Trablusgarp'taki faaliyetlerinin ekonomik temelli olduğu mesajı resmi ağızlardan iletildi. Böylece Osmanlı yönetiminin kendilerine karşı siyasî veya askerî bir tedbir almasına gerek olmadığı izlenimi verildi. Osmanlı yönetimi de İtalya'dan ültimatom alıncaya kadar İtalya'nın böyle bir girişimde bulunamayacağını düşünmekte ve tedbiri elden bırakmamış olmak adına bazı faaliyetlerde bulunmaktaydı. Diğer taraftan ise italyan kamuoyu ve basınında İtalya'nın 1911 yılı içinde Trablusgarp'ı işgal edeceği yönünde haberler ve söylentiler artmaya başlamıştı. ${ }^{40}$ Bu söylentilerin yoğunlaştığı sırada Başbakan Giolitti ve Dışişleri Bakanı Giuliano Roma'dan ayrılarak tatillerini geçirmek üzere farklı şehirlere gitmişlerdi. Giolitti İtalyan kamuoyunun savaş söylentileri ile çalkalandığı bir ortamda gerçekleştirmiş olduğu bu davranışı şöyle açıklamaktaydı: 'Bundan maksat herkese siyasî mühim bir mesele olmadığı hissini vermek idi. $O$ zaman Trablusgarp meselesinde pek hararetli olan gazeteler böyle mühim bir zamanda Roma'dan uzaklaşmış olmamdan ve Dışişleri Bakanı ile teması kesmiş olmamdan dolayı bana şiddetle hücum etmekte idiler. Fakat bu gazetelerin aleyhimde savurdukları küfürler beni pek ziyade memnun ediyordu, çünkü bu şiddetli neşriyat takip ettiğim planın tamamen muvaffak olduğuna delalet etmekte ve tabii Türk Hükümeti'nin de şüphelerini izale eylemekteydi. Nitekim verdiğimiz ültimatom ile mezkur Hükümet tamamen gafil avlanmış oldu. ${ }^{41}$

Özellikle 1911 Nisan ayında Fransa'nın Fas'a asker çıkarması ve Almanya'nın Agadir Limanı'na savaş gemilerini göndermesinin ardından İtalya Fransa ile imzalamış olduğu 1900 ve 1902 yıllarındaki anlaşmalara dayanarak bu fırsatı kaçırmak istememiştir. Çünkü bu anlaşmalara göre Fransa Fas'a karşı bir hareket gerçekleştirdiğinde İtalya da Trablusgarp'a karşı hareket serbestîsine sahip olacaktı. İşte bu fırsatı kaçırmak istemeyen İtalyan hükümeti Osmanlı'nın Trablusgarp'ta takip etmiş olduğu politikaların kendilerini çok güç durumda bıraktığı ve bu durumun da italya'yı Trablusgarp'a karşı hareket etmek zorunda bıraktığı senaryosu altında Trablusgarp'ı işgal

${ }^{40}$ Bayur, a.g.e., $2 / 1$, s.75-81.
${ }^{41}$ Kurtcephe, a.g.e., s.36.

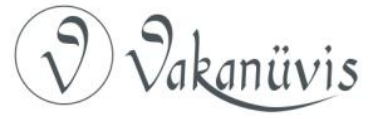


fikrini 1911 Temmuz'undan itibaren Avrupa devletlerine anlatmaya başlamıştır. ${ }^{42}$

İtalya ilk olarak İngiltere'ye başvurmuştur. İngiltere Dışişleri Bakanı Grey gerçekten İtalyanlar kötü durumdaysalar ve Osmanlı yönetimi bunu düzeltmek için hiçbir çaba sarf etmiyorsa İtalya'nın bugüne kadar takdire şayan bir sabır gösterdiğini ve mesele eğer barış içinde çözülemeyecek noktaya gelir ise İtalya'nın girişeceği herhangi bir harekete İngiltere'nin engel olmayacağı gibi diplomatik destek de vereceğini belirtmiştir. ${ }^{43}$ Bu noktada İngiltere'nin İtalya'ya bu denli sıcak yaklaşmasına neden olan etkenler Temmuz ayı başında Fas'ın Agadir Limanı'na savaş gemisi göndermesi ile Almanya'nın Hindistan yolu üzerinde bir liman elde etmek istemesinin ortaya çıkması ve italya'nın Almanya'nın yanında daha fazla yer almasının engellenmesi olarak belirtilebilir. ${ }^{44}$

İtalya'nın Trablusgarp'ın işgali konusunda en çok güvendiği ülke Fransa'ydı. Çünkü iki ülke arasında imzalanan 1900 ve 1902 anlaşmalarına göre Fransa Fas'ı işgal ettiği takdirde İtalya da Trablusgarp'a karşı harekete geçebilecek ve her iki ülke de bu haklarını kabul edeceklerdir. 1911 Nisan ayında Fransa Fas'a asker çıkardığında Italya buna sessiz kalarak üzerine düşeni yapmış, aynısını şimdi Fransa'dan beklemiş ve nihayetinde Fransa da üzerine düşeni yaparak İtalya'nın Trablusgarp teşebbüsüne desteğini açıklamıştır. ${ }^{45}$

Rusya ise Italya ile 1909 yılında imzalamış oldukları Racconigi Antlaşması çerçevesinde İtalya'nın bu teşebbüsünü olağan karşıladığını belirttikten sonra İtalya'nın bu işgal sırasında Rusya'nın karşısına birdenbire bir Osmanlı paylaşımı meselesi çıkarmaması ve Avrupa devletlerini Balkanlarda müdahaleye mecbur edecek bir durum yaratmaması hususunda çok dikkatli davranması gerektiğini belirtmiştir. $^{46}$

42 Robert Mantran, Osmanlı Imparatorluğu Tarihi II, Çeviren: Server Tanilli, Adam Yayınları, İstanbul, Mart 1999, s.248.

${ }^{43}$ Armaoğlu, a.g.e., s.637.

${ }^{44}$ Bayur, a.g.e., 2/1, s.82-83

${ }^{45}$ Bayur, a.g.e., 2/1, s.83.

${ }^{46}$ Kurtcephe, a.g.e., s.40, Bayur, a.g.e., 2/1, s.83-84

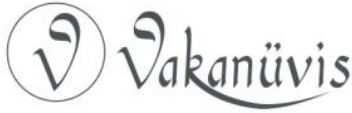


İtalya, müttefiki Almanya'ya başvurduğunda da Almanya bu girişimi haklı ve meşru bulmuş ancak bu desteğinin son derece gizli tutulmasına çok büyük çaba sarf etmiştir. Bu gizliliğin gerekçesi olarak Almanya'nın bir taraftan ittalya'nın müttefiki sıfatına sahip olmasına rağmen diğer taraftan da Osmanlı Devleti ile olan siyasî ve ticarî ilişkilerden elde ettiği menfaatleri gösterilebilir. ${ }^{47}$

Avusturya-Macaristan da müttefiki ittalya'nın bu girişimini olumlu karşılamış ancak aynı Rusya'nın tavsiyeleri gibi bu durumun Balkanlara sirayet etmemesi gerektiğinden bahsetmiştir. ${ }^{48}$

Görüldüğü üzere İtalya 19.yy’ın son yıllarında imzalamış olduğu bazı antlaşmalar veya Avrupa içi dengeler vasıtası ile Trablusgarp'a yönelik girişimlerinin önünü açmayı başarmıştır. Daha önceden gerçekleştirmiş olduğu askerî hazırlıklarını diplomatik başarı ile taçlandıran İtalya artık Osmanlı yönetimine sunacağı savaş sebebinin kâğıtlarını hazırlamaya başlamıştı.

Osmanlı tarafında ise İtalya'nın bu son hazırlıklarına karşı bazı girişimler olmamış değildir. Özellikle yönetime İtalya'nın amaçları hakkında sunulan raporlar Meclis'te tartışmalara sebep olmuş ve tedbirler alınması gerektiği yönünde sesler yükselmeye başlamıştır. Roma Elçisi Kazım Bey İtalya'nın emellerini çok iyi bir şekilde gözlemlemiş ve bunları yönetime bir rapor şeklinde sunmuştur. Bu rapor çerçevesinde Kazım Bey İtalya'nın Trablusgarp'ı daha önce işgal etmediğine pişman olduğunu ve işgale kalkışması ihtimaline karşı Trablusgarp'ın kuvvetlendirilmesi gerektiğini belirtmektedir. ${ }^{49}$ Osmanlı Hükümetine göre ise İtalya'nın Trablusgarp'ı işgal etmesi şu sebeplerden ötürü imkânsızdı; İtalya'nın Trablusgarp ile ilgili bütün talepleri zaten karşılanmıştı, her türlü ekonomik imtiyazı elde eden İtalya'nın böyle bir işgale kalkışması için bir sebep yoktu, dost Almanya müttefiki İtalya'nın işgale kalkışmasını kesinlikle engelleyecektir, Tunus

47 Hale Şıvgın, Trablusgarp Savaşı ve 1911-1912 Türk-italyan ilişkileri, Türk Tarih Kurumu Basımevi, 1989, s.29.

${ }^{48}$ Avusturya-Macaristan her ne kadar bu durum karşısında sessiz kalmışsa da yönetim içinde Balkanlar ve özellikle Adriyatik Denizi üzerindeki nüfuzun arttırıması noktasında italya'nın bu teşebbüsünü bir fırsat olarak değerlendiren yöneticiler de olmuştur. Bayur, a.g.e., 2/1, s.105-106.

${ }^{49}$ Şıvgın, a.g.e., s.39.

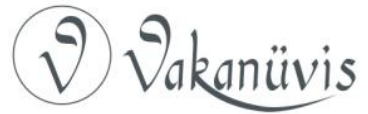


meselesinden dolayı araları iyi olmayan Fransa, İtalya'nın hâlâ hak iddia ettiği Tunus'a komşu olmasını istemeyecektir, Bingazi'nin Mısır'a verilmesini isteyen İngiltere de İtalya'nın bölgeye gelmesini istemeyecektir, Avusturya-Macaristan ise zaten İtalya ile iyi ilişkiler içinde değildi. ${ }^{50}$ Osmanlı yönetiminin kendince sıralamış olduğu bu gerekçeler neticesinde yönetim İtalya'nın işgal girişimine olanak vermemekteydi. Sadece bu sayılan gerekçeler şüphesiz haklı görülebilirse de Osmanlı yönetiminin Avrupa siyasî dengeleri içinde gerçekleştirilen gizli anlaşmalardan haberdar olmaması böyle bir yanılgı içine düşmesine neden olmuştur.

İtalya'nın gerçekleştirdiği faaliyetler ile ilgili elçiliklerden gelen raporlar ve gerek iç gerekse de dış basında yer alan haberlerin Osmanlı yönetimini kaygılandırmaya başlaması neticesinde yönetim bütün sefaretlere bir genelge göndererek bulundukları ülkeler nezdinde Italyan hükümetine karşı girişimlerde bulunmaları gerektiğini belirtmiştir. ${ }^{51}$ Osmanlı yönetiminin aldığı ilk ciddi tedbir ise silah, cephane ve erzak yüklü Derne Gemisini 18 Eylül'de Trablusgarp'a göndermesi olmuştur. 12.500 mavzer tüfeği, 600 sandık mavzer cephanesi, 500 çuval un, 500 çuval peksimet ve 200 asker elbisesi taşıyan Derne gemisi halk tarafından büyük bir coşku ile karşılanmıştır. $^{52}$ Derne gemisinin gelişinden son derece rahatsız olan İtalya ise bütün savaş hazırlıklarını tamamlamış ve çeşitli limanlardan hareket eden İtalyan savaş gemileri Trablusgarp'a en yakın bölgelerde beklemeye başlamışlardır. Diplomatik çabalarını neticelendirmeye çalışan İtalya için sadece bir savaş bahanesi bularak işgale başlamak kalmıştı.

\section{Eylül Notası}

İtalya savaşa yönelik ilk hamlesi olarak 23 Eylül 1911'de İstanbul'a bir nota gönderdi. Buna göre; Osmanlı subayları ve ittihat ve Terakki Cemiyeti üyelerinin cahil ve mutaassıp halkı İtalyanlar aleyhine kışkırttıkları, bunun sonucu olarak Trablusgarp ve Bingazi civarında bulunan İtalyanların can güvenliğinin tehlikeye girdiği hatta canlarını

\footnotetext{
${ }^{50}$ Kurtcephe, a.g.e., s.45.

${ }^{51}$ Bayur, a.g.e., 2/1, s.85.

${ }^{52}$ Kurtcephe, a.g.e., s.54.
}

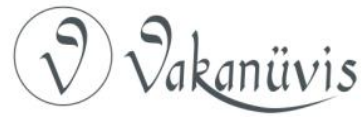


tehlikede gören bazı ailelerin bölgeyi terk etmeye hazırlandıkları, Osmanlı yönetiminin bu durumları yatıştırmakta başarılı olamadığı belirtilerek Trablusgarp'a asker, silah, cephane ve erzak yüklü vapurların gönderilmesi kınanmakta idi. ${ }^{53}$ Osmanlı yönetimi verdiği cevapta böyle bir durumun kesinlikle olmadığını belirterek Osmanlı'nın Trablusgarp'ta emniyeti ve asayişi sağlayabilecek kudrette olduğunu belirtmiştir.

İtalya limanlarından yola çıkan İtalyan savaş gemileri yavaş yavaş artık Trablusgarp açıklarında görülmeye başlamıştı. Özellikle Osmanlı'nın olası bir yardım gemisini engellemek amacıyla geçen bütün gemileri durdurup kontrol etmekteydiler. 25 Eylül'den itibaren 3 Italyan savaş gemisi Trablusgarp ve Bingazi kıyılarını sıkı bir gözetim altına almıştı. ${ }^{54} \mathrm{Bu}$ yüzden Bingazi'ye gönderilmek istenen tüfek ve cephaneleri taşıyan gemi de italyanlara yakalanma tehlikesinden dolayı yola çıkarılmamıştır. Yavaş yavaş i̇talyan savaş gemilerinin görülmeye başlamasından itibaren Trablusgarp'ta bulunan birliklerin nasıl hareket edeceğine dair Harbiye Nazırı Mahmut Şevket Paşa şifreli bir telgraf göndermiştir. Bu telgrafta genel hatları ile İtalyanlar nasıl muamelede bulunurlarsa aynı şekilde karşılık verilmesi emredilmekte, başarısızlık halinde hemen iç bölgelere çekilerek burada bir hükümet kurulmalı, iç bölgelerde çete muharebeleri yapılmalı, silah ve cephane halka dağıtılmak üzere derhal iç bölgelere taşınmalı ve Tunus üzerinden istanbul ile irtibat kurulmaya çalışılmalıydı. ${ }^{55}$

Osmanlı Devleti gelişmeler karşısında nabzını tuttuğu başta Almanya olmak üzere, Fransa ve Rusya'dan tatmin edici cevaplar alamamış İtalya'nın ise Trablusgarp'a yönelik niyetini bu defa gizlemediğine şahit olmuştur.

\section{Eylül Notası}

Italya ise son diplomatik girişimlerini neticelendirmeye çalışmaktaydı. Bu bağlamda 26 Eylül tarihinde zaten daha önceki

53 Mehmed Selahaddin Bey, Ittihat-Terakki'nin Kuruluşu ve Osmanlı Devleti'nin Yıkılışı Hakkında Bildiklerim, Sadeleştiren: Ahmed Varol, İnkılab Yayınları, İstanbul, Eylül 1989, s.39.

${ }^{54}$ Genelkurmay ATASE, a.g.e., s. 30 .

${ }^{55}$ Kurtcephe, a.g.e., s.55-56.

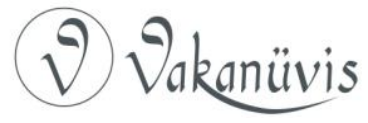


antlaşmalar çerçevesinde İtalya'nın Trablusgarp üzerindeki haklarını kabul etmiş olan Avusturya-Macaristan bu durumun Balkanlara sıçramaması teminatı verilerek ikna edildi. Daha sonra hem italya hem de Osmanlı İstanbul elçisi Marchall üzerinden Almanya nezdinde girişimlerde bulunmuşlar ve bu noktada İtalyan diplomasisi galip gelmiştir. Marchall olası bir işgalin Türkiye'de hükümetin düşmesine neden olabileceğini, bu durumun bir ihtilaf doğuracağını, yabancı devlet vatandaşlarına karşı kötü muamele yapılma ihtimalinin ortaya çıkacağını ve bunun neticesinde ìtalya ve diğer devletlerin savaş gemilerini göndermek zorunda kalacaklarını belirterek bu surette Şark Meselesi'nin tekrar ortaya çıkması gibi vahim bir durumla karşı karşıya kalabilecekleri uyarısında bulunmuşsa da İtalyan elçi artık geriye dönüşün olmadığını belirtmiş, sorunun mahiyet değiştirdiğini, şimdi özellikle Akdeniz dengesinin söz konusu olduğunu ve bu dengenin İtalya'nın Trablusgarp'ı alması halinde kurulabileceğini belirtmiştir. ${ }^{56}$

Tüm bu gelişmelerin neticesinde 28 Eylül'de İtalya Osmanlı yönetimine reddolunması halinde savaş ilan edeceğini belirten notayı vermiştir. 24 saat süreli bu notada İtalya; Trablusgarp ve Bingazi'nin Kuzey Afrika'nın diğer kısımlarına nazaran uygarlıktan uzak kaldığını, kendilerinin bu hususta Osmanlı Devleti'ni defalarca uyardıklarını, Osmanlı́nın bu bölgelerdeki italyan iktisadî faaliyetlerine son dönemlerde engellemeler çıkardığını, bölgede Türk subayları ve hükümet makamlarınca İtalyan halk üzerinde kötü muamelede bulunulması yönünde tahrikler yapıldığını, bu durumun sadece italyanlar için değil diğer milletler için de tehlike arz ettiğini, kendilerinin bütün uyarılarına rağmen bölgeye askerî nakliye gemilerinin gönderildiğini, gemilerin gönderilmesinin durumu tamamen kötüleştirdiğini ve kendilerinin bu sevkiyatın yarattığı tehlikenin önünü almaya mecbur bırakıldıklarını belirterek İtalya'nın bundan böyle çıkarlarını, şerefini ve haysiyetini korumak için Trablusgarp ve Bingazi'yi askerî kuvvet kullanarak işgale karar verdiği vurgulanmaktadır. ${ }^{57}$ Ayrıca 24 saat içinde bu notaya cevap verilmediği takdirde işgale başlanacağı belirtilmiştir. Osmanlı kabinesi tarafından

${ }^{56}$ Lütfü Simavi, Son Osmanlı Sarayında Gördüklerim, Örgün Yayınevi, 2. Baskı, İstanbul, 2004, s.160., Kurtcephe, a.g.e., s.61-62.

${ }^{57}$ Kurtcephe, a.g.e., s.64, Bayur, a.g.e., 2/1, s.93-95.

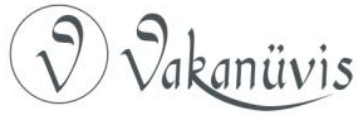


29 Eylül'de verilen cevapta; bölgenin gelişmemiş olması Meşrutiyet öncesi yönetimlerin sorumluluğuna dâhil edilmekte (Filvaki ahvalin bitarafane bir surette tettkikı Hükümeti Meşrutai Osmaniyenin idarei sabıkanın eseri olan bir hal ve mevkiden dolayı muatebe edilemeyeceğini teybine kifayet eder), bölgedeki asayiş bozukluğu iddiaları reddedilmekte, Derne gemisinin ise zaten Italyan notalarından önce yola çıktığı ve erzak taşıdığı belirtilmekte, İtalya'nın işgal kararından vazgeçmesi halinde İtalya'ya istediği bütün iktisadî imtiyazların verilebileceği ifade edilmektedir. ${ }^{58}$

íki ülkenin nota teatisi ile birlikte savaşın kaçınılmazlığının zaten önceden farkında olan diğer ülkeler kendi güvenlikleri için de savaş hazırlıkları yapmışlardır. Bu bağlamda Rusya Osmanlı'nın paylaşılması ihtimalini de göz önünde bulundurarak Sarıkamış'a asker ve mühimmat yığmış, savaşın Balkanlara sıçraması ihtimalini değerlendiren Bulgaristan savaş hazırlıklarını hızlandırarak sınır boylarındaki asker ve mühimmatını arttırma faaliyetlerine girişmiş, savaş başlamadan önce tarafsızlığını ilan eden Yunanistan tedbiri elden bırakmayarak tehlikeli olabileceğini düşündüğü bölgelere asker sevk etmeye başlamış, Sırbistan ve Karadağ da aynı şekilde savaşa karşı hazırlıklar gerçekleştirmişler ve savaşın Balkanlara yayılmasından en fazla endişe duyan ülke olan Avusturya-Macaristan da böylesi bir olasılı̆̆ın gerçekleşmesine karşılık sınırlarına asker yığmaya başlamıştır. ${ }^{59}$

\section{Savaş i̇lanı ve Sonrası}

İtalya 28 Eylül'de vermiş olduğu notanın süresinin dolmasını beklemeden 29 Eylül'de Osmanlı'ya karşı savaş ilan ettiğini Osmanlı hükümetine iletmiştir. Savaş ilanı mektubu kendisine verilen Sadrazam Hakkı Paşa bunun ardından istifa etmiş ve yerine daha önce 7 defa Sadrazam olmuş, tecrübeli Said Paşa hükümet kurmuştur. ${ }^{60}$ Said Paşa da daha henüz görevine resmen başlamamış olduğu süre içinde İtalya'nın savaştan vazgeçirilmesi hususunda Avrupalı devletlerin

\footnotetext{
${ }^{58}$ Bayur, a.g.e., 2/1, s.95-97., Kurtcephe, a.g.e., s.65.

${ }^{59}$ Kurtcephe, a.g.e., s.67-68.

60 Yılmaz Öztuna, Başlangıcından Zamanımıza Kadar Türkiye Tarihi, 12.Cilt, Hayat Kitapları, 1967, s.210.
}

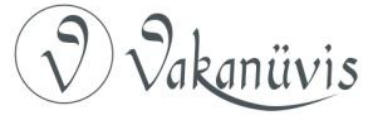


nabızlarını tutmuş ancak sonucun kaçınılmaz olduğunu idrak etmiştir. İtalya'nın savaş ilanının ardından Osmanlı topraklarında yaşayan İtalyanların işlerinden çıkarılması kararının yanında Osmanlı’nın diğer devletler nezdinde daha kötü bir duruma düşmemesi için İtalyanların korunması yönünde de kararlar alınmıştır. ${ }^{61}$

26 Eylül gecesi itibariyle ablukaya başlayan Italyan gemilerinin sayısının savaş ilanı ile birlikte artmaya başlaması karşısında Osmanlı yönetimi kendisi için en uygun savaş taktiklerini geliştirmek zorunda kalmıştı. Harbiye Nazırı Mahmut Şevket Paşa'nın daha önce göndermiş olduğu talimatlar çerçevesinde elinden geldiğince mücadele edecek olan birlikler başarısız olmaları halinde iç bölgelere çekilerek mücadeleye devam edeceklerdi. Ayrıca bölge genelinde oldukça geniş bir nüfuz alanına sahip Şeyh Senusi'nin de yardımı sağlanmaya çalışılacaktı.

İtalyan temsilcileri 30 Eylül'den itibaren gemilerinden Trablusgarp şehrine gelip yetkililerle görüşerek teslim olmalarını istemeye başlamıştır. Şehirde bulunan yetkililer de istanbul ile irtibata geçemediklerini belirterek zaman kazanmaya çalışmışlardır. Fakat 3 Ekim'de italya artık şehri bombalamaya başlamış ve menzilleri daha uzun olan İtalyan bombaları karşısında tutunamayan Türk birlikleri, gönüllüler ile birlikte İstanbul'dan gelen talimat çerçevesinde daha iç bölgelere çekilmişlerdir. Şehrin bombalanmaya başlaması ile birlikte şehirde asayiş bozulmuş, halk üzerinde büyük bir korku ve yılgınlık hüküm sürmeye başlamıştır. Osmanlı dönemi itibariyle son derece elverişli koşullar altında özellikle ticaret alanında ön plana çıkan Yahudiler, güçlü ticarî ilişki temin ettikleri İtalyan firmalarının devleti olan İtalya tarafından şehrin işgal edilmesinden son derece memnun bir şekilde işgal süresince onların bölge üzerindeki en önemli müttefikleri haline gelmişlerdir. ${ }^{62}$ Bu gelişmelerle birlikte Trablusgarp şehri 5 Ekim'de düşerken, bir gün önce Tobruk'u işgal eden İtalyanlar, 16 Ekim'de Derne'yi, 20 Ekim'de de Bingazi'yi işgal etmişlerdir.

${ }^{61}$ Savaş ile birlikte İtalyanlara yönelik uygulamalar hakkında daha geniş bilgi için bakınız: Nurdan İpek Şeber, "Arşiv Belgelerine Göre Trablusgarp Savaşı'nın Osmanlı Topraklarındaki İtalyan Tebaaya Yansımaları", Osmanlı Araştırmaları, Sayı:38, 2011, s.237-262.

${ }^{62}$ Ahmida, a.g.m., s.307., Kurtcephe; a.g.e., s.84.

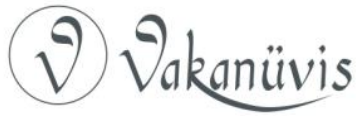


1882 yılından bu yana Mısır'ı elinde bulunduran İngiltere İtalyanların savaş ilan etmelerinin ardından Mısır ticaretinde önemli rol oynayabilecek bir konuma sahip Sellum Limanı konusunda fırsatı kaçırmak istememiştir. İtalyan saldırısı ihtimaline karşılık Trablusgarp sınırları içinde yer alan Sellum Limanı'nın Mısır’a verilmesi talebi karşısında İngiltere ile bir mücadeleyi göze alamayan Osmanlı yönetimi de bu isteği kabul etmek zorunda kalmıştır. ${ }^{63}$ Fransa da Trablusgarp sınırları içinde yer almasına rağmen Tunus üzerinden Afrika içlerine geçmesine olanak sağlayan bazı vahaları bu savaş sırasında tekrar gündeme getirmiştir. Trablusgarp sınırları içindeki Tarat Vadisi'ne Aralık 1911'den itibaren yerleşmeye başlayan Fransa'nın savaş sırasında Tunus sınırını kapatacağı imasında bulunması ve direnmesi karşısında Fransa'yı da karşısında alamayacak olan Osmanlı yönetimi Fransa'nın da Tarat Vadisi'ni işgal etmesini kabul etmiştir. ${ }^{64}$

Trablusgarp'ın işgale uğraması Osmanlı toplumu ve diğer bazı toplumlar nezdinde de çok büyük bir tepkiye sebep olmuştur. Osmanlılık şuuru içerisinde ırk, din, dil, mezhep fark etmeksizin Osmanlı toplumunun bütün kesimlerinden işgale karşı gayrı resmi bir seferberlik ilan edilmiş, protesto gösterileri düzenlenmiş, çok sayıda gönüllü Trablusgarp'ta savaşmak için resmî makamlara müracaat etmiş, azımsanmayacak sayıda insan da kendi çabaları ile Trablusgarp'a ulaşmaya çalışmış, Osmanlı toprakları dışında İngiltere'den Hindistan'a uzanan bir coğrafya içerisinde çok sayıda maddi ve manevi destek gelmiş ve hatta İtalya'nın bu işgal girişimi karşısında Osmanlı topraklarında yaşayan bazı İtalyan vatandaşları milliyetçi bir zaviyeden ziyade Osman aidiyeti çerçevesinde Osmanlı tabiiyetine geçerek taraflarını belli etmişlerdir. ${ }^{65}$ Toplumun göstermiş olduğu bu tepkinin resmi hüviyet sahiplerindeki tezahürü niteliğinde bu işgal genç Türk

63 Bayur, a.g.e., 2/1, s.103-104., Sellum Limanı aynı zamanda savaşa destek mahiyetinde silah, cephane, iletişim ve insan kaynağı açısından da önemli bir nokta idi. Beehler, a.g.e., s.71-72.

${ }^{64}$ Kurtcephe, a.g.e., s.88-89.

65 Osmanlı ve diğer toplumların göstermiş oldukları tepkileri ele alan bir çalışma için bakınız: Ahmet Öğreten, “italya'nın Trablusgarb’a Saldırısı Karşısında Osmanlı Toplumunun Tavrı", Tarih ve Medeniyetler Tarihi, Bildiriler Kitabı, 5. Cilt, Atatürk Kültür, Dil ve Tarih Yüksek Kurumu Yayınları., 2012, s.2277-2300.

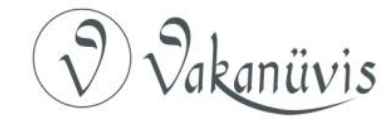


subayları arasında da rahatsızlığa neden olmuş ve Enver Bey, Kolağası Mustafa Kemal, Eşref Bey (Kuşçubaşı), Paris Ataşesi Ali Fethi Bey, Süleyman Askerî Bey gibi daha yüzlerce genç subay Trablusgarp'a ulaşabilme gayreti göstermişlerdir. ${ }^{66}$ Osmanlı yönetimi ise italyanlara karşı tüm imkânların kullanılarak mücadelenin devam ettirilmesi emrini vermiş, Enver bey ve diğer subayların Trablusgarp'a gitmek üzere yola çıktıklarını telgrafla Trablusgarp Fırka Kumandanlı̆̆ı'na bildirmiştir. ${ }^{67}$ Gazeteci Mustafa Şerif takma ismini kullanan M. Kemal de yanında Yakup Cemil Bey ile birlikte Mısır üzerinden Trablusgarp'a ulaşmak için yola çıkmıştır. Vatan topraklarının ücra köşelerini müdafaa için yola çıkan Mustafa Kemal yolda hastalanarak İskenderiye'ye dönmek zorunda kalmış ve 15 gün hastanede kalmasına rağmen mücadeleden vazgeçmemiştir. ${ }^{68}$ ilk olarak Tobruk'a geçen $\mathrm{M}$. Kemal burada 27 Kasım 1911'de Binbaşı rütbesine yükseltilerek Tobruk Komutanı sıfatına sahip olmuştur. ${ }^{69}$ Mustafa Kemal bundan sonra Trablusgarp'ın işgaline engel olmak için icracı olarak yer aldığı askerî mücadelelerin istanbul ile temas halinde belirli bir plan ve koordinasyon çerçevesinde yürütülmesini çok zorlu şartlar altında sağlama gayreti göstermiştir. ${ }^{70}$ Bölgedeki birliklerin komutanlıklarını vekâleten yürüten Neşet Bey'in yerine genç subay Ali Fethi Bey'in kurmay başkanı olması ile birlikte direnişin tüm komutası genç subayların eline geçmiş olmaktaydı. ${ }^{71}$ Padişahın damadı olması ve cepheye direnişe gelmiş olması bölge halkı üzerinde çok büyük etki yaratan Enver Bey Trablusgarp'ta büyük coşku ile karşılanmış ve

66 Bayram Bayraktar, Muhammet Karakaş, Hasan Özsoy, Çağdaş Türkiye Tarihi, İnkılâp Kitapevi, İstanbul, 2002, s.61., Sina Akşin, Türkiye Tarihi, 4. Cilt, Cem Yayınevi, 8.Basım, İstanbul, Kasım 2005, s.38.

${ }^{67}$ Hakan Bacanlı, " 1911-1912 Osmanlı-İtalyan Savaşı Ve Örikağasızade Hasan Sırrı'nın "Hukuk-i Düvel Nokta-i Nazarından Osmanlı-italya Muhârebesi" Adlı Eseri”, Askerî Tarih Araştırmaları Dergisi, Sayı 21, Şubat 2013, s. 47.

${ }^{68}$ Hüsnü Özlü, “Arşiv Belgeleri Işığında Osmanlı-Ittalyan Harbi’nde (1911-1912) Trablusgarp’ın İşgali ve Derne Muharebelerinde Binbaşı Mustafa Kemal", Uluslararası Avrasya Sosyal Bilimler Dergisi, Yıl:5, Cilt:5, Sayı:16, Eylül 2014, s.251.

${ }^{69}$ Genelkurmay ATASE, a.g.e., s.37.

70 Özlü, a.g.m., s.262-263.

${ }^{71}$ Kurtcephe, a.g.e., s.92.

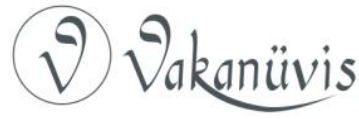


cepheye gelen gönüllülerin sayısında bir artışa neden olmuştur. Genç subaylar ile birlikte güçlenen mücadele İtalyanlara karşı zaferler kazanmaya başlayınca İtalya bu başarısızlığını gölgelemek amacıyla bölgeyi tamamen ele geçirememiş olduğu halde 5 Kasım 1911'de Trablusgarp ve Bingazi'yi ilhak ettiğini ilan etmiştir. ${ }^{72}$

Genç subayların gelmesi ile ivme kazanan direniş hareketinin şüphesiz en önemli ismi Senusi Şeyhi Ahmet Şerif olmuştur. Şeyh her zaman halifeye olan bağlılığını ifade etmiş ve italyanlara karşı mücadele vermiştir. Söz konusu İtalyan karşıtı mücadele bölgeye ulaşan Türk askerleri ile birlikte daha düzenli ve aşiretler arasında belirli bir koordinasyon çerçevesinde sürdürülmeye başlanmış ve İstanbul'un vermiş olduğu talimatlar doğrultusunda Enver Bey, Mustafa Kemal ve Ali Fethi Bey gibi isimlerin şekil verdiği kıyı şeridinde topyekûn saldırıdan ziyade iç bölgelere çekilen İtalyan askerî unsurlarının parça parça baskına uğratılması planı çerçevesinde yerli unsurların da yardımı ile İtalya uzun bir müddet zor durumda

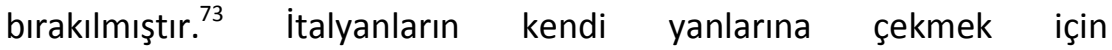
gerçekleştirdikleri bütün faaliyetleri görmezlikten gelen Şeyh italyanlara karşı mücadele için cihat fermanları ilan etmiştir. Senusilerin mücadelesi Uşi Antlaşması'ndan sonra da devam etmiştir. ${ }^{74}$

\section{İtalya'nın Trablusgarp Dışındaki Mücadelesi}

İtalya'nın Osmanlı yönetiminin direncini kırmak amacıyla savaşı çeşitli bölgelere yaydığını görmekteyiz. İtalyan birlikleri savaşın başlarında Osmanlı Donanması'nın nerede olduğunu tam olarak bilemediği için kendisine gelen istihbarat doğrultusunda ilk olarak Adriyatik Denizi'nde kaçakçılığı önlemek için devriye görevinde bulunan ve savaş ilanından haberi olmayan 3 Osmanlı gemisini

72 Erdal Aydoğan, İsmail Eyyüpoğlu, Bahaeddin Şakir Bey'in Bıraktığı Vesikalara Göre ittihat ve Terakki, Alternatif Yayınları, 1.Baskı, Ankara, Şubat 2004 , s.632.

73 İsrafil Kurtcephe, “Trablusgarp’ın İtalyanlarca İşgali, Mustafa Kemal ve Arkadaşlarının Direnişe Katılmaları”, AÜ Türk İnkılap Tarihi Enstitüsü Dergisi Atatürk Yolu, Yıl:3, Sayı:6, Cilt:2, Kasım 1990, ss. 361-375.

${ }^{74}$ Uşi Antlaşması kendisi için çok büyük bir hayal kırıklığı olan Şeyh Ahmed Şerif zaman zaman İtalyanları ağır yenilgilere uğratmıştır. Nihat Azamat, "Ahmed Şerif Senusî", İslam Ansiklopedisi, Cilt: 36, 2009, s.527.

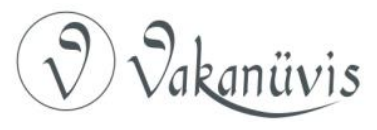


bombalayarak batırmış, kaçan bir Türk gemisi de sığındığı Preveze Limanı ile birlikte bombalanmıştır. ${ }^{75}$ italya'nın Adriyatik Denizi'nde böyle bir saldırı gerçekleştirmiş olması savaşın Balkanlara yayılmasından çekinen Avusturya-Macaristan ve Rusya'nın tepkisine neden olmuştur.

Osmanlı donanması ise 28 Eylül günü sabah saatlerinde Beyrut Limanı'ndan ayrılmış ve İtalya'nın savaş ilanından bîhaber vaziyette İtalyan gemilerine yakalanmadan 1 Ekim günü Çanakkale Boğazı'na gelmiştir. ${ }^{76}$ İtalyanların Osmanlı donanmasını yakalayamamış olması kendi iç kamuoyunda bir başarısızlık olarak addedilmişse de aslında Osmanlı Donanması'nın Çanakkale Boğazı'na sığınıp tekrar İtalyanların karşısına çıkamaması i̇talyanların boğazdan ötede tek egemen kuvvet olmasını ve Trablusgarp'a gitmesi muhtemel bütün yardımları kontrol etmesini sağlamıştır. ${ }^{77}$

İtalya'nın bu savaşı yaymış olduğu bir diğer alan Akdeniz ve Ege Denizi olmuştur. İtalya'nın böylesi bir girişimi daha önce imzalamış olduğu bazı anlaşmaların hükümlerine aykırılık teşkil ediyordu. Bu noktada da İtalya'ya en fazla karşı çıkan ülke Avusturya-Macaristan olmuştur. Bu ülke İtalya'nın böylesi bir girişiminin İtalya ile imzalamış oldukları Üçlü İttifak Antlaşması'nın özellikle 7. maddesine aykırı olduğunu söyleyerek İtalya'nın bu girişimini kabul etmemiştir. ${ }^{78}$ Almanya savaş alanının genişlemesi tehlikesine dikkat çekerken, Rusya İtalya'nın bu girişimine fazla muhalefet göstermeyerek bir anlamda destek olmuş, Fransa ve İngiltere de kendi menfaatlerine zarar gelmemesine dikkat eder bir tutum sergilemişlerdir. ${ }^{79}$ Osmanlı Devleti ise İtalya'nın bu yönde bir girişimi olup olmadığı hususunda Avrupalı devletlerden yeterince bilgi alamamasının ardından Osmanlı topraklarında yaşayan İtalyanların sınır dışı edilmesi veya savaş esiri

\footnotetext{
${ }^{75}$ Kurtcephe, a.g.e., s.97-98., Beehler, a.g.e., s.30-31.

${ }^{76}$ Beehler, a.g.e., s.32; Şıvgın, a.g.e., s.103.

${ }^{77}$ Kurtcephe, a.g.e., s.100-101.

${ }^{78}$ Wrigley, a.g.m., s.322.

${ }^{79}$ Şıvgın, a.g.e., s.99.
}

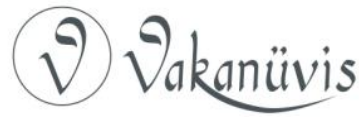


olarak kabul edilmesi kararını almıştır. ${ }^{80}$ Bu kararlar bütün Avrupalı devletlerden tepki görmüştür.

Osmanlı yönetiminin 1912 yılı Mart ayında italya'dan Rusya'ya gönderilirken ele geçirdiği raporda İtalya'nın bu tarihten itibaren savaşa iki ay devam edebilmesi için gerekli paraya sahip olmadığı, savaşı devam ettirebilmek için borç almak zorunda olduğu, Trablusgarp'taki askerlerinin manevî bakımdan tam bir çöküntü içinde olduğu, İtalya'ya geri dönmek istedikleri ve bu sebeplerden dolayı savaşa bir an önce son vermek niyetinde olan italya'nın bu şartlarda Akdeniz ve Ege Denizi'nde bir harekâta girişmesinin mümkün olmadığı belirtiliyordu. ${ }^{81}$ Bu bilgiler çerçevesinde Mart 1912'den sonraki süreçte Osmanlı Devleti İtalya'nın savaşı Akdeniz'e yayma ihtimalinin Osmanlı'yı barışa zorlamak için bir manevra olduğuna inanmış ve ona göre politikalar yürütmüştür.

İtalya yönetimi 24 Şubat 1912'de Beyrut'u bombalamaya başlamıştır. İtalyanların ilk olarak Beyrut'u bombalamalarının altında Beyrut'un bütün ilahî dinlerce kutsal sayılan Kudüs'ün kapısı konumunda olması, bölgede çok sayıda Avrupalının yaşıyor olması, böylelikle Avrupalı Devletlerin durumdan rahatsız olarak Osmanlı Devleti üzerinde barış için baskı kuracaklarının tahmin edilmesi etkili olmuştur. ${ }^{82}$ Ancak bu bombalama tüm Avrupa Devletleri nezdinde değil sadece Fransa'da büyük bir memnuniyetsizliğe neden olmuş ve bazı İtalyan vatandaşlarının Beyrut'tan ayrılmasına sebep olmuştur. ${ }^{83}$

İtalya bundan sonra Çanakkale Boğazı'na yönelmiştir. Başta Rusya olmak üzere diğer büyük devletlerin de ticarî faaliyetlerinde oldukça önemli bir yer işgal eden Çanakkale Boğazı'na yönelik İtalya'nın olası saldırısına karşı Rusya, Fransa, İngiltere, Almanya ve AvusturyaMacaristan İtalya'yı uyarmışlardır. Ülkelerin bu uyarılarda bulunmasında şüphesiz temel etken İtalya'nın böyle bir saldırı

${ }^{80}$ Oğuz Karakartal, Türk Kültüründe Italyanlar, Eren Yayıncılık, İstanbul, 2002, s.31.

${ }^{81}$ Kurtcephe, a.g.e., s.106.

${ }^{82}$ Bacanlı, a.g.m., s.51.

83 Baron Joseph von Hammer; Büyük Osmanlı Tarihi, Cilt:9, İkra Okusan, İstanbul, 1992, s.636.

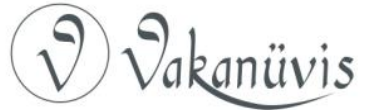


gerçekleştirmesi halinde Osmanlı yönetiminin Boğazları tüm gemi geçişlerine kapatacağını büyük devletlerin İstanbul'daki büyükelçileri aracılığıyla ilan etmiş olmasıdır. ${ }^{84}$ Ege Denizi'ndeki olası italyan operasyonlarına hazırlık mahiyetinde daha önceden mayınlarla döşenen Çanakkale Boğazı'na beklenen İtalyan saldırısı Meclis-i Mebusan'ın seçimler sonrası açıldığı ilk gün, 18 Nisan 1912'de gerçekleştirildi ve Osmanlı yönetimi daha önce de belirttiği üzere Çanakkale Boğazı'nı tüm geçişlere kapattı. ${ }^{85}$ Osmanlı Devleti bu hareketi ile ticarî kayba uğrayacak büyük güçlerin İtalya'ya bu tür saldırılarda bulunmaması için baskı yapacaklarını umut ederken İtalya da diğer taraftan aynı büyük güçlerin Osmanlı yönetimi üzerinde Trablusgarp Savaşı'nın kendi istekleri doğrultusunda sonlandırıması için baskı yapacağı beklentisi içindeydi. ${ }^{86}$ Aslında söz konusu büyük güçlerin gerek Osmanlı gerekse de İtalya yönetimleri nezdinde savaşın başladığı andan itibaren savaşın kendi çıkarlarını ihlâl edecek bir hüviyet kazanmadan sonlandırılması için girişimleri olmuş ancak henüz başarılı olamamışlardır. ${ }^{87}$ Tüm bu siyasî uğraşların gölgesinde Çanakkale Boğazı'na saldırıya geçen İtalyan gemileri mayınlar ve güçlü savunma karşısında geri çekilmek zorunda kalmıştır. $^{88}$ Yapılan diplomatik girişimler neticesinde Büyük devletlerin tepkileri karşısında ${ }^{89}$ Osmanlı yönetiminin 2 Mayıs itibariyle Boğazları açmasının ardından İtalya İttihat ve Terakki Yönetimi'nin hükümetten düştüğü bir sırada 17 Temmuz gecesi Çanakkale Boğazı'na bir saldırı daha

${ }^{84}$ Nuri Karakaş, “Askeri ve Siyasi Yönleriyle İtalyan Donanması'nın Çanakkale Boğazı Harekâtı (18 Nisan 1912), Gazi Akademik Bakış, Cilt: 6, Sayı: 12, Yaz 2013, s.89.

${ }^{85}$ Beehler, a.g.e., s.86-89.

${ }^{86}$ Karakaş, a.g.m., s.94-101.

${ }^{87}$ Konu ile ilgili yakın tarihli bir çalışma için bakınız: William Clarence Askew, "Europe's Efforts at Peacemaking During the Turco-Italian War", The Southwestern Social Science Quarterly, Vol:18, No: 4, March 1938, s.363-375.

${ }^{88}$ Alan Palmer, Osmanlı Imparatorluğu Son Üç Yüz Yıl Bir Çöküşün Yeni Tarihi, Çeviren: Belkıs Çorakçı Dişbudak, Sabah Kitapları, 1994, s.238-239.

${ }^{89}$ Bu noktada ticarî yönden en fazla zararı gören Rusya ve İngiltere'nin ön planda olduğu görülmektedir. Diğer taraftan Osmanlı Yönetimi'nin Ingiltere'den destek sağlama gayreti İngilizlerin aleyhine bir tutum sergilemenin de önüne geçmekteydi. Karakaş, a.g.m., s.101-105.

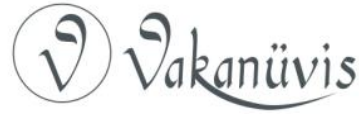


gerçekleştirmiş ancak yine başarısız olmuştur. ${ }^{90} \mathrm{Bu}$ defa Boğazları kapatmayan Osmanlı yönetimi askerî önlemlerin arttırılması kararını almıştır. Bu bağlamda Almanya'dan çok sayıda torpil ve top satın alınmış, Boğazların savunmasını yapmakla görevli askerî birliklerin sayısı arttırılmış, Harbiye ve Bahriye Nazırlıklarınca İtalyan saldırılarının kazandırdığı veriler doğrultusunda yeniden Boğazları savunma planları geliştirilmiştir ki bu tedbirler bir anlamda 1915 Çanakkale Savaşı'ndaki zaferin temellerini teşkil etmiştir. ${ }^{91}$

İtalya'nın savaşı yaymak istediği bir diğer alan Ege Denizi'ndeki adalar olmuştur. Bu bağlamda İtalya 1912 Nisan ayı ortalarından itibaren Ege Denizi'nde bulunan adaları işgal etmeye başlamıştır. Ege Denizi'nde Osmanlı Donanması'nın bulunmaması, Rodos hariç adalarda askerî kuvvet olmayışı gibi askerî sebeplerin yanında bu adalarda yaşayan Rumların İtalyanların en büyük yardımcıları olmaları gibi etkenler çerçevesinde adaların işgali noktasında i̇talya hiç zorlanmamıştır. ${ }^{92}$ italya ilk olarak 24 Nisan'da Stampalia adasını işgal etmiş, 17 Mayıs itibariyle Rodos'u işgal etmiş, bunların haricinde 10 ada ve $15^{\prime}$ i bulan küçük adacık işgali ile birlikte Rodos ile On iki Adayı ele geçirmiş oldu. ${ }^{93}$

İtalya'nın savaşı yaydığı bir diğer alan Kızıldeniz olmuştur. İtalya'nın savaşı buraya taşımasında Osmanlı'yı barışa zorlamanın yanında Eritre'de bulunan İtalyan kuvvetlerini Yemen'de bulunan Türk kuvvetlerinin olası bir saldırısından korumak ve daha da önemlisi Osmanlı'nın Kızıldeniz ve Sudan yoluyla Bingazi'deki Senusilere yardım götürmesini engellemek amaçları da vardı. ${ }^{94}$ Trablusgarp Savaşı'nın başladığı sıralarda Osmanlı yönetimi Arap yarımadasında İmam Yahya

\footnotetext{
90 italya bu saldırısında her ne kadar başarısız olmuşsa da İtalyan filosu Boğaz içerisinde 11 mil kadar yakalanmadan ilerlermiş, bu durum ittalyan filo komutanının terfi etmesini Türk komutanın ise görevinden alınmasını beraberinde getirmiştir. Beehler, a.g.e., s,114-115.

${ }^{91}$ Kurtcephe, a.g.e., s.118-119.,

92 Bacanlı, a.g.m., s.55; Şıvgın, a.g.e., s.110.

93 Necdet Hayta; 'The Question of the Aegean Islands and Their Loss by Turkey', The Great Ottoman-Turkish Civilisation, Volume I, Editör: Kemal Çiçek, Ankara, 2000, s.710.

${ }^{94}$ Kurtcephe, a.g.e., s.130.
}

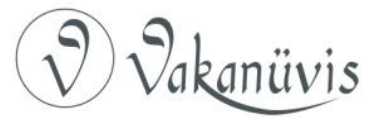


ve Seyyit İdris'in çıkarmış olduğu isyanlar ile uğraşmaktaydı. İmam Yahya isyanı bastırılmıs ise de Seyyit İdris İtalyanlar ile de irtibata geçerek mücadelesine devam etmiştir. ${ }^{95}$ İtalya'dan para ve silah yardımı alan Seyyit İdris kendisini halk nezdinde meşru kılabilmek için akrabası olan Senusi ismini kullanmasına rağmen sürekli ve tam bir halk desteği sağlayamamış ancak halk nezdinde fazla itibar görmeyen Seyyit İdris ile İtalya'nın Osmanlı'ya karşı mücadeleleri Uşi Antlaşması imzalanıncaya kadar devam etmiştir. ${ }^{96}$

\section{Uşi Barış Antlaşması}

Gerek İtalya'nın gerek de Osmanlı́nın birbirlerini barışa zorlayan manevralar içinde bulunmalarının ardından 1912 yılı sonlarına doğru artık iki ülke arasında gizli görüşmeler yapılmaya başlanmıştır. Her iki ülke de kendi taleplerinde ısrar etmişse de Osmanlı yönetiminin o sıralarda Balkanlarda kendisine karşı oluşmaya başlayan cephe ile birlikte İtalya'ya nazaran talepler konusunda daha esnek davranmak zorunda kalan taraf olduğunu söyleyebiliriz. Bu bağlamda karşılıklı olarak iletilen barış şartlarının ardından ilk barış görüşmeleri büyük bir gizlilik içinde Lozan'da 12 Temmuz 1912 'de başlamıştır. ${ }^{97}$ Tarafların süren müzakereler süresince taleplerinin değişiklik gösterdiği görüşmeler devam ederken Said Paşa istifa etmiş yerine, içinde Kamil ve Hüseyin Hilmi Paşalar gibi eski sadrazamların bulunmasından dolayı 'Büyük Kabine' ismi verilen Gazi Ahmet Muhtar Paşa liderliğinde bir hükümet kurulmuştur. ${ }^{98}$ İtalya bu hükümetin dışişleri bakanının Ermeni olan Noradonkyan Efendi olmasından dolayı son derece memnun olmuştur. Yeni hükümet savaş bölgesindeki yetkililerden cephanenin

\footnotetext{
${ }^{95}$ Bayur, a.g.e., 2/1, s.45-47.

${ }^{96}$ İtalya'nın Kızıldenizdeki faaliyetleri ve Seyyit İdris'in konumu ile ilgili bakınız: Mehmet Korkmaz, "Kızıldenizde Rekabet: 1911-1912 Trablusgarp Harbi Sırasında Kızıldeniz'de Osmanlı İtalyan Mücadelesi", Askerî Tarih Araştırmaları Dergisi, Sayı: 21, Şubat 2013, s.17-43.

${ }^{97}$ Yaklaşık bir hafta sonra Osmanlı Hükümeti'nin düşmesi dolayısıyla yaşanan kriz nedeniyle ilk görüşmeler 28 Temmuz'a ertelenmiştir. Askew, a.g.m., s.374.

98 Feridun Emecen; 'Kuruluştan Küçük Kaynarcaya', Osmanlı Devleti ve Medeniyeti Tarihi, Editör: Ekmeleddin İhsanoğlu, İslam Tarih, Sanat ve Kültür Araştırmaları Merkezi (IRCICA) Yayınları, İstanbul, 1994, s.122.
}

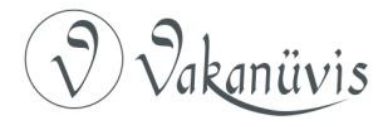


bittiği, cephane sevk edilmezse durumun daha da kötü olacağı, halkın bir kısmının artık barış yapılması gerektiğine inanmaya başladığı şeklinde bilgiler almıştır. ${ }^{99}$ Bunun ardından mecliste gerçekleştirilen görüşmeler neticesinde yönetim yeni şartlarını belirlemiş ve bu şartlar çerçevesinde Nabi ve daha evvel Roma elçiliğinde görev yapan Fahrettin Bey görüşmeleri yürütmek üzere görevlendirilmişlerdir. ${ }^{100}$

Türk ve İtalyan temsilciler arasında bu defa İsviçre'nin Caux şehrinde 13 Ağustos'ta başlayan barış görüşmeleri Uşi'de devam etmiştir. Bu sıralarda Osmanlı Devleti Balkanlarda Bulgaristan, Sırbistan, Yunanistan ve Karadağ'ın seferberlik ilan ettiği haberini almış ve bu devletlerin Osmanlı'ya karşı bir savaş başlatacakları yorumları yapılmaya başlanmıştır. ${ }^{101}$ Balkanlarda bir savaşın patlak vermesi, adaları işgal altında tutan İtalya'nın İzmir ve Trakya'daki sahil bölgelerini bombalama tehdidi ${ }^{102}$ gibi durumlar Osmanlı Devleti'ni zor durumda bırakmıştır. Bu bağlamda barış şartlarını yenileyen Osmanlı Devleti ile İtalya arasında 15 Ekim 1912'de Uşi Barış Antlaşması imzalanarak savaşa son verilmiştir. ${ }^{103}$ Uşi Antlaşması 4 ekli ve 4 . eki açık ilan edilecek bir gizli antlaşma şeklinde imzalanır ve buna göre antlaşmanın açık olan 4. ekinde özetle şunlar yer almaktadır: Barışın ilan edildiği, önce Osmanlı yönetiminin Trablusgarp'ta bulunan askerlerini ardından Italyanların Adalardaki askerlerini geri çekeceği, tutsakların salıverileceği ve genel af ilan edileceği, iki ülke arasındaki eski antlaşmaların yeniden yürürlüğe gireceği, Osmanlı topraklarında işten çıkartılan İtalyanların yeniden işe alınacağı, Düyun-u Umumiye'nin Trablusgarp'taki gelirlerinin eskiden olduğu gibi ödenileceği, kapitülasyonların kaldırılması hususunda İtalya'nın yardımcı olacağı. ${ }^{104}$

\footnotetext{
${ }^{99}$ Kurtcephe, a.g.e., s.204-205.

${ }^{100}$ Bayur, a.g.e., 2/1, s. 433; Kurtcephe, a.g.e., s.207-208.

101 Abdullah Khan Yasamee; 'The Ottoman Empire and European Alliances,1815-1914', The Great Ottoman-Turkish Civilisation, Volume I, Editör: Kemal Çiçek, Ankara, 2000, s.415.

102 Hermann, "The Paralysis...", s.353.

103 Mehmet Maksudoğlu, Osmanlı Tarihi 1289-1922, Elif Yayınları, Ekim 2003, s.465.

104 Bayur, a.g.e., 2/1, s.439-440.
}

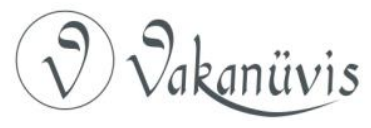


Antlaşmanın gizli olan metninde ise şu hususlar belirtilmektedir: Osmanlı Padişahı'nı temsil edecek Naibüssultan isminde bir görevlinin atanacağı ve bu atamada İtalyan hükümetinin de onayının aranacağı, Osmanlı Devleti'nin antlaşmayı müteakip 3 gün içinde bir Padişah fermanı yayınlatacağı ve bunu takiben de İtalya'nın bir Krallık emri yayınlatacağı, Osmanlı Devleti'nin Trablusgarp ve Bingazi'ye silah, mühimmat ve asker göndermemeyi kabul ettiği, italya'nın Balkan sorununun Osmanlı çıkarlarına en uygun şekilde sonuçlandırılması için Osmanlı'ya her türlü yardımda bulunacağı, Osmanlı Devleti'nin Seyyit İdris ve taraftarları için bir genel af ilan edeceği, her iki tarafın da bu antlaşma Meclis-i Mebusan'a götürülene kadar gizli tutmayı kabul edeceği. ${ }^{105}$

\section{Sonuç}

19.yy.'ın ikinci yarısında Almanya ile aynı dönemlerde millî birliğini kurmuş olan İtalya, Avrupa siyasî dengeleri içerisinde Bismarck liderliğindeki Almanya kadar etkin bir konumda yer almaktansa kendisine sömürge alanları bulmaya yönelmiştir. Özellikle Bismarck'ın Fransa'ya karşı oluşturmaya çalıştığı ve aynı şekilde Fransa'nın da bunu engellemeye yönelik çabaları çerçevesinde İtalya ne Almanya ne de Fransa ile yaptığı antlaşmalara sadık kalmıştır. Bu bağlamda ìtalya kendi çıkarları doğrultusunda sadece sömürge elde edebilme mücadelesine girişmiştir. Daha 19.yy'ın başlarından itibaren kendisine hedef seçtiği Tunus'un Berlin Kongresi'nde siyasî dengeler çerçevesinde Fransa'ya 'hediye' edilmesinin ve 1881 'de Fransa tarafından işgal edilmesinin ardından İtalya ilk başlarda uzak bir coğrafya olan Habeşistan'ı elde etmeye çalışmış ancak burada da başarısız olmasından sonra yönünü Osmanlı'nın Afrika'nın kuzeyinde egemenliği altında kalan son toprak parçası olan Trablusgarp'a çevirmiştir. Osmanlı Devleti'nin bir çöküş dönemi yaşadığının farkında olarak politikalar geliştiren İtalya, Avrupa siyasî dengelerini çok iyi okuyarak çeşitli manevralarda bulunmuş ve Trablusgarp'a yönelik girişeceği hareket için bütün büyük Avrupa devletlerinin onayını almıştır. İtalya'nın gerçekleştirmiş olduğu bu manevralardan habersiz olan Osmanlı yönetimi ise diplomasiyi iyi ve yeterince kullanamamanın

${ }^{105}$ Kurtcephe, a.g.e., s.219-220

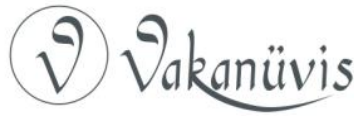


zararlarını Trablusgarp'ın işgali öncesi fazlasıyla görmüştür. Osmanlı yönetimi bazı denge unsurlarını zaten İtalya'nın daha öncesinden anlaştığı ülkeler nezdinde kullanmaya çalışmışsa da bu girişimler başarısızlığa mahkûm olmuştur. İtalya bölge üzerinde 19.yy.'ın sonlarından itibaren siyasî, kültürel ve ekonomik bazı faaliyetlerde de bulunmuştur. Bu faaliyetler ile bölge üzerindeki nüfuzunu arttırmış ve özellikle Osmanlı'nın çöküş döneminde olduğu bir sırada bu alanlarda bir cazibe merkezi olmuştur. İtalya'nın savaş gerekçesinin temelini de zaten bölgenin medeniyetten mahrum bırakıldığı iddiası oluşturmuştur ki günümüzde de bazı büyük uluslararası aktörler kendi çıkarları doğrultusunda müdahale amacı güttükleri bölgelerin ya terörizm yuvası olduğunu ya da demokrasiden yoksun bölgeler olduğunu belirterek küresel çapta barış, huzur ve istikrarın temini için bu bölgelere demokrasi ve medeniyet götürmeyi amaçladıklarını iddia ederek müdahalede bulunmaktadırlar.

1911-12 yılları arasında italya'nın bütün koşullarını hazırladığı Osmanlı'nın ise inanmak istemediği savaş başladı ve Osmanlı sadece bölge halkının ve bölgeye ulaşmış olan Türk subaylarının mücadeleleri ile sürdürdüğü bu savaşı Balkan Savaşı'nın başlamasından sadece bir hafta sonra 15 Ekim 1912' de Uşi Barış Antlaşması ile neticelendirmiştir. $\mathrm{Bu}$ antlaşma ile Trablusgarp'ı kaybeden Osmanlı yönetimi bunun yanında İtalya'nın tavsiyesi/tehdidi ile Balkan Savaşı sırasında Rodos ve On iki Ada'yı da İtalya'ya bırakmıştır. Ancak Rodos ve On İki Ada II. Dünya Savaşı'na kadar İtalya'da kalmış ve savaş sonrası yapılan düzenlemeler ile Yunanistan'a bırakılmıştır. Bu şekilde toprak kayıplarına devam eden Osmanlı yönetimi daha barış görüşmeleri devam ederken ortaya çıkan Balkan Savaşları ve sonrasında da I. Dünya Savaşı ile oldukça zorlu bir sürecin içine girmiştir. Böylelikle Trablusgarp Savaşı Osmanlı diplomasi tarihinde kötü gidişatın ilk emarelerinden biri olarak yerini almıştır. Gerçekleşen bu savaşlar, dönemin güçlü devletlerinin 'hasta adam' Osmanlı üzerindeki emelleri ve kötü yönetim gibi nedenlerden ötürü Osmanlı Devleti hızlı bir şekilde sona yaklaşmış ve Trablusgarp Savaşı başta olmak üzere vatan için cephelerde gönüllü mücadele edenler devletin yeni bir hüviyet

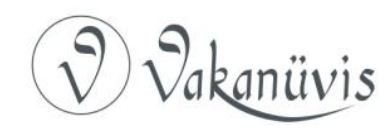


kazanarak idamesini temin etmeye Mustafa Kemal önderliğinde muvaffak olmuşlardır. ${ }^{106}$

\section{Kaynakça}

\section{Kitaplar}

Akşin, Sina, Türkiye Tarihi, 4. Cilt, Cem Yayınevi, 8.Basım, İstanbul Kasım 2005.

Armaoğlu, Fahir, 19. Yüzyıl Siyasi Tarihi 1789-1914, Alkım Yayınevi, 4.Baskı, istanbul 2007.

Ateş, Toktamış, Siyasal Tarih I, İstanbul Üniversitesi iktisat Fakültesi Yayınları, 1982.

Aydoğan, Erdal, Eyyüpoğlu, İsmail, Bahaeddin Şakir Bey'in Bıraktığı Vesikalara Göre ittihat ve Terakki, Alternatif Yayınları, 1.Baskı, Ankara Şubat 2004.

Ayverdi, Samiha, Türk Tarihinde Osmanlı Asırları, Kubbealtı Neşriyatı, 4.Baskı, İstanbul 1999.

Bayraktar,Bayram, Karakaş,Muhammet, Özsoy, Hasan, Çağdaş Türkiye Tarihi, İnkılâp Kitapevi, İstanbul 2002.

Bayur, Yusuf Hikmet, Türk Inkılâbı Tarihi, Cilt:1 Kısım: 1, Türk Tarih Kurumu Basımevi, Ankara 1991.

Bayur, Yusuf Hikmet, Türk Inkılâbı Tarihi, Cilt:2, Kısım:1, Türk Tarih Kurumu Basımevi, Ankara 1991.

Beehler, Commodore W. H., 1911-1912 Türk-italyan Savaşı, Çevirmen: Leyla Yıldırım, ilgi Kültür Sanat Yayınları, İstanbul 2014.

Best, Antony, Hanhimäki, Jussi M., Maiolo, Joseph A., Schulze, Kirsten E,. 20. Yüzyılın Uluslararası Tarihi, Çeviren: Taciser Ulaş Belge, Siyasal Kitabevi, 2012.

Briggs, Asa, Clavin, Patricia, Modern Europe 1789-1989, Longman, 1997.

Çelebi, Mevlüt, Milli Mücadele Döneminde Türk-Italyan iliş̧kileri, Dışişleri Bakanlığı Stratejik Araştırmalar Merkezi, SAM Notları No.1/99, Ankara Haziran 1999.

${ }^{106}$ Bu noktada Trablusgarp Savaşı, çetin mücadeleler sonucunda kurulacak yeni Türkiye Cumhuriyeti Devleti'nin kurucusu olacak Mustafa Kemal için aldığı askerî eğitimin savaş meydanlarında tatbiki, teşkilatlanma noktasında tecrübe, askerî idare ve sevk konularında çok önemli şeyler kazandıran bir "ilk savaş' olmuştur. Hale Şıvgın, "Mustafa Kemal'in İlk Savaşı", ATATÜRK Araştırma Merkezi Dergisi, Cilt: IV, Sayı: 10, Kasım 1987, s.190-191.

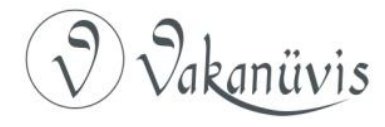


Genelkurmay Askerî Tarih ve Stratejik Etüt Başkanlığı, 1911-1912 OsmanlıItalyan Harbi ve Kolağası Mustafa Kemal, Kültür ve Turizm Bakanlığı Yayınları, Ankara Haziran 1985.

Hammer, Baron Joseph von, Büyük Osmanlı Tarihi, Cilt: 9, İkra Okusan, İstanbul 1992.

Karakartal, Oğuz, Türk Kültüründe Italyanlar, Eren Yayıncılık, İstanbul 2002.

Karal, Enver Ziya, Osmanlı Tarihi, IX. Cilt, Türk Tarih Kurumu Basımevi, Ankara 1996.

Kurtcephe, İsrafil, Türk Italyan Iliş̧kileri (1911-1916), Türk Tarih Kurumu Basımevi, Ankara 1995.

Maksudoğlu, Mehmet, Osmanlı Tarihi 1289-1922, Elif Yayınları, Ekim 2003.

Mantran, Robert, Osmanlı Imparatorluğu Tarihi II, Çeviren: Server Tanilli, Adam Yayınları, İstanbul Mart 1999.

Öztuna, Yılmaz, Başlangıcından Zamanımıza Kadar Türkiye Tarihi, 12.Cilt, Hayat Kitapları, 1967.

Palmer, Alan, Osmanlı Imparatorluğu Son Üç Yüz Yıl Bir Çöküşün Yeni Tarihi, Çeviren: Belkıs Çorakçı Dişbudak, Sabah Kitapları, 1994.

Selahaddin Bey, Mehmed, Ittihat-Terakki'nin Kuruluşu ve Osmanlı Devleti'nin Yıkılışı Hakkında Bildiklerim, Sadeleştiren: Ahmed Varol, İnkılab Yayınları, İstanbul Eylül 1989.

Shaw,Stanford J., Shaw, Ezel Kural, History of the Ottoman Empire and Modern Turkey, Volume II, Reform, Revolution and Republic: The Rise of Modern Turkey 1808-1975, Cambridge University Press, 1977.

Simavi, Lütfü, Son Osmanlı Sarayında Gördüklerim, Örgün Yayınevi, 2.Baskı, İstanbul 2004.

Soutou, Georges-Henri, Avrupa Birliği Tarihi 1815'ten Günümüze, Fransızcadan Çeviren: Eylem Alp, Bilge Kültür Sanat Yayınları, 1. Basım, Şubat 2014.

Şıvgın, Hale, Trablusgarp Savaşı ve 1911-1912 Türk-italyan Ilişkileri, Türk Tarih Kurumu Basımevi, Ankara 1989.

Turan, Şerafettin, Türk Devrim Tarihi, Bilgi Yayınevi, 1. Basım, Kasım 1991.

Ünal, Tahsin, Türk Siyasi Tarihi 1700-1958, Kamer Yayınları, 6.Baskı, İstanbul 1998.

\section{Makaleler}

Ahmida, Ali A., "From Tribe to Class: The Origins and the Politics of Resistance in Colonial Libya", Africa: Rivista trimestrale di studi $e$ documentazione dell'Istituto italiano per l'Africa e l'Oriente, Anno 63, No. 2, La Libia nella storia del Mediterraneo. Atti del Convegno, Roma, 10-12 maggio 2003 (Giugno 2008), ss.297-310.

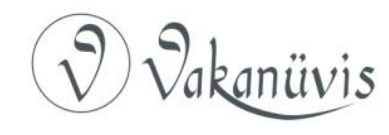


Askew, William Clarence, "Europe's Efforts at Peacemaking During the Turco-Italian War", The Southwestern Social Science Quarterly, Vol:18, No: 4, March 1938, ss.363-375.

Bacanlı, Hakan, “ 1911-1912 Osmanlı-Italyan Savaşı Ve Örikağasızade Hasan Sırrı'nın "Hukuk-i Düvel Nokta-i Nazarından Osmanlı - İtalya Muhârebesi" Adlı Eseri", Askerî Tarih Araştırmaları Dergisi, Sayı 21, Şubat 2013, ss.45-80.

Cunsolo, Ronald S., "Libya, Italian Nationalism, and the Revolt Against Giolitti", The Journal of Modern History, Vol:37, No:2, June 1965, ss.186-207.

Emecen, Feridun, 'Kuruluştan Küçük Kaynarcaya', Osmanlı Devleti ve Medeniyeti Tarihi, Editör: Ekmeleddin İhsanoğlu, İslam Tarih, Sanat ve Kültür Araştırmaları Merkezi (IRCICA) Yayınları, İstanbul 1994.

Hayta, Necdet, 'The Question of the Aegean Islands and Their Loss by Turkey', The Great Ottoman-Turkish Civilisation, Volume I, Editör: Kemal Çiçek, Ankara 2000.

Herrmann, David G., "The Paralysis of Italian Strategy in the Italian-Turkish War, 1911-1912", The English Historical Review, Vol.104, No. 411, April 1989, ss.332-356.

İnan, Âfet, "Trablusgarp'ta Hürriyete Karşı İsyan”, Belleten, Cilt: VIII, Sayı:31, Temmuz 1944, ss.387-401.

Karakaş, Nuri, “Askeri ve Siyasi Yönleriyle İtalyan Donanması'nın Çanakkale Boğazı Harekâtı (18 Nisan 1912), Gazi Akademik Bakış, Cilt: 6, Sayı: 12, Yaz 2013, ss.81-109.

Koloğlu, Orhan, "Libya, From the Ottoman Perspective (1835-1918)", Africa: Rivista trimestrale di studi e documentazione dell'Istituto italiano per I'Africa e l'Oriente, Anno 63, No. 2, La Libia nella storia del Mediterraneo. Atti del Convegno, Roma, 10-12 maggio 2003 (Giugno 2008), ss.275-282.

Korkmaz, Mehmet, “Kızıldeniz'de Rekabet: 1911-1912 Trablusgarp Harbi Sırasında Kızıldeniz'de Osmanlı İtalyan Mücadelesi", Askerî Tarih Araştırmaları Dergisi, Sayı: 21, Şubat 2013, ss.17-43.

Kurtcephe, İsrafil, “Trablusgarp’ın İtalyanlarca İşgali, Mustafa Kemal ve Arkadaşlarının Direnişe Katılmaları”, AÜ Türk Inkılap Tarihi Enstitüsü Dergisi Atatürk Yolu, Yıl:3, Sayı:6, Cilt:2, Kasım 1990, ss. 361-375.

Öğreten, Ahmet, “ítalya'nın Trablusgarb’a Saldırısı Karşısında Osmanlı Toplumunun Tavrı", Tarih ve Medeniyetler Tarihi, Bildiriler Kitabı, 5. Cilt, Atatürk Kültür, Dil ve Tarih Yüksek Kurumu Yayınları, 2012, s.2277-2300.

Özlü, Hüsnü, “Arşiv Belgeleri Işığında Osmanlı-Italyan Harbi’nde (19111912) Trablusgarp'ın İşgali ve Derne Muharebelerinde Binbaşı Mustafa Kemal”, Uluslararası Avrasya Sosyal Bilimler Dergisi, Yıl:5, Cilt:5, Sayı:16, Eylül 2014,ss.249-171.

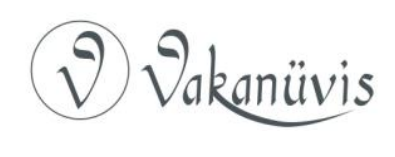


Şeber, Nurdan Ipek, "Arşiv Belgelerine Göre Trablusgarp Savaşı'nın Osmanlı Topraklarındaki İtalyan Tebaaya Yansımaları", Osmanlı Araştırmaları, Sayı:38, 2011, ss.237-262.

Şıvgın, Hale, "Mustafa Kemal'in illk Savaşı", ATATÜRK Araştırma Merkezi Dergisi, Cilt: IV, Sayı: 10, Kasım 1987, ss.187-195

Webster, Richard A., "The Political and Industrial Strategies of a Mixed Investment Bank: Italian Industrial Financing and the Banca Commerciale 1894-1915", VSWG: Vierteljahrschrift für Sozial- und Wirtschaftsgeschichte, 61. Bd, H.3, 1974, ss.320-371.

Wrigley, W. David, "Germany and the Turco-Italian War, 1911-1912", International Journal of Middle East Studies, Vol.11, No.3, May 1980, ss.313338.

Yasamee, Abdullah Khan, 'The Ottoman Empire and European Alliances,1815-1914', The Great Ottoman-Turkish Civilisation, Volume I, Editör: Kemal Çiçek, Ankara 2000.

\section{Ansiklopedi Maddeleri}

Azamat, Nihat, "Ahmed Şerif Senusi”, İslam Ansiklopedisi, Cilt:36, 2009, ss.527-529.

Kavas, Ahmet, "Trablusgarp", İslam Ansiklopedisi, Cilt.41, 2012, ss.288291.

Kavas, Ahmet, "Senusiyye", islam Ansiklopedisi, Cilt: 36, 2009, ss.536-537. 